\title{
LATOSSOLOS DO BRASIL: UMA REVISÃO
}

\author{
João Carlos Ker(*)
}

\begin{abstract}
This paper presents a review on Latosols (oxisols) genesis, classification and use in tropical Brazil. Chemical, physical and mineralogical aspects are throughly discussed, as well as their relationship with soil use and management. Some problems of definition are considered for all types of Latosols recognized in the Brazilian System of Soil Classification. The role of clay minerals such as kaolinite, gibbsite and iron oxides (namely hematite, goethite, magnetite and maghemite) is discussed against the background of soil classification and soil fertility aspects. The ammount of trace-elements and the relationship between these elements $(\mathrm{Mn}, \mathrm{Cu}, \mathrm{Zn}, \mathrm{Co})$ and latosols genesis and classification is shown, illustrating the trend of higher values for those soils developed from mafic rocks and alike. The geographic distribution of latosols classes in Brazil (namely Ferriferous, Dusky-Red, Dark-Red, Red-Yellow, Yellow, Brown, Humic, Una variation and Pallid) is given. Finnaly, a general view on phosphorous adsorption for the various types of latosols is presented, illustrating the importance of the clay mineralogy as a primary factor of controlling $\mathrm{P}$ availability in these soils.
\end{abstract}

\section{HISTÓRICO E CONCEITUAÇÃO}

O termo "Latosol", deriva de "laterite"(1) e "solum", ambos de origem latina, significando, respectivamente, tijolo ou conotando material altamente intemperizado, e solo, foi proposto pelo pedólogo americano Charles E. Kellog, em uma conferência americana sobre classificação de solos realizada em Washington em 1949 (Lemos, 1966; Cline, 1975; Ségalen, 1994). Os Latossolos, como utilizado no Brasil, guardam certa correspondência com os Oxisols, Sols Ferralitiques e Ferralsols dos sistemas americano, francês e FAO, respectivamente.

A introdução deste termo como classe de solo objetivou grupar solos mais intemperizados das regiões tropicais, até então denominados "laterite" e "lateritic soils", de definição pouco precisa, genérica e confusa, onde solos distintos eram agrupados em uma mesma classe (Kellog, 1949,1950; Lemos, 1966; Cline, 1975; Segalen, 1994).

O conceito inicial de Latossolo (Kelllog, 1949) contemplava solos cujas características encontravam-se fortemente relacionadas à intemperização e lixiviação intensas e responsáveis pelas baixas atividade das argilas; capacidade de troca de cátions; relações moleculares sílica/ alumínio $\left(\mathrm{SiO}_{2} / \mathrm{Al}_{2} \mathrm{O}_{3}=\mathrm{Ki}\right)$ e sílica/óxidos de ferro e alumínio $\left(\mathrm{SiO}_{2} / \mathrm{Al}_{2} \mathrm{O}_{3}+\mathrm{Fe}_{2} \mathrm{O}_{3}=\mathrm{Kr}\right)$. Além disso, os solos designados por Latossolos, além de profundos, de coloração relativamente homogênea com matizes avermelhadas e/ou amareladas, apresentariam distribuição mais ou menos uniforme de argila ao longo do perfil, elevada estabilidade de agregados e baixo conteúdo de silte em relação à argila. O termo deveria ser empregado independente da presença ou não de laterita, na sua concepção original.

Pela definição original de Kellog para "Latosol", observa-se que aspectos quantitativos ainda não eram contemplados, certamente em razão do pouco conhecimento que havia para essa classe de solos, ou dos solos tropicais, em geral, na época. Mesmo assim, a intensão de empregar o termo "Latosol" no sistema americano é mencionada no esboço de classificação de Thorp \& Smith (1949), e parece ter influenciado pedólogos brasileiros. Tanto é assim, que este termo foi empregado em vários trabalhos de levantamento de solos de algumas áreas do Brasil, iniciados na década de cinquenta (BRASIL, 1958, 1960 e 1962).

Com o desenvolver do sistema americano de classificação de solos, os solos latossólicos foram agrupados na ordem dos "Oxisols" não sendo mais empregado o termo "Latosol" naquele sistema de classificação. Para tanto, estabeleceu-se a definição do horizonte subsuperficial óxico ("oxic horizon" - EUA, 1960, 1975, 1994), que inspirou com adequações, a criação do horizonte B latossólico (Bw) diagnóstico da classe dos Latossolos, no sistema brasileiro de classificação de solos (Bennema \& Camargo, 1964; Camargo et al., 1987; EMBRAPA- SNLCS, 1988).

(1) "Laterite" ou laterita (L. later = tijolo, ou material fortemente endurecido). Empregado por Buchanam em 1807 (ALEVA, 1992), em referência às grandes massas de argilas endurecidas irreversivelmente por efeito de dessecação, ricas em ferro, de coloração amareloocre e vermelha, sem qualquer aparência de estratificação, observadas por aquele autor na Índia, e utilizada pelas populações locais na construção civil, tal seu estado de dureza. Com o tempo, este termo ganhou amplo significado e a definição de Latossolo parece mais associada à da laterita, no sentido de material altamente intemperizado, rico em óxidos secundários de ferro e alumínio, ou ambos, pobre em bases e silicatos primários, podendo conter quantidades consideráveis de quartzo e caulinita (ALEVA, 1992, fazendo considerações a respeito do uso do termo "laterite", por vários pesquisadores, ao longo do tempo). 
Desde sua criação no final da década de cinquenta (BRASIL, 1958; 1960), o horizonte B latossólico passou por adequações até última versão (EMBRAPA-SNLCS, 1988), descrita a seguir:

1. apresenta espessura mínima de $50 \mathrm{~cm}$, textura mais fina que franco arenosa com baixos teores de silte, de maneira que a relação silte/argila seja menor que 0,7 ;

2. apresenta na fração $<0,05 \mathrm{~mm}$, corrigidos para fração TFSA, menos de $4 \%$ de minerais primários facilmente decomponíveis, ou menos de $6 \%$ de muscovita; admite-se a presença de pequenas quantidades de argilominerais interestratificados e, ou, ilita, na fração menor que $0,005 \mathrm{~mm}$ (silte + argila), porém não deve conter mais que traços de minerais do grupo das esmectitas;

3. a relação molecular $\mathrm{SiO}_{2} / \mathrm{Al}_{2} \mathrm{O}_{3}(\mathrm{Ki})$ deve ser menor que 2,2;

4. não deve apresentar mais que $5 \%$ do volume ocupado por materiais pouco alterados, ainda guardando resquícios do material de origem;

5. grande estabilidade de agregados, sendo o grau de floculação igual ou próximo de $100 \%$, à exceção dos horizontes mais ricos em matéria orgânica ou eletropositivos;

6. CTC menor que $13 \mathrm{cmol} / \mathrm{kg}$, descontada a participação do carbono orgânico; $\mathrm{e}^{\mathrm{c}}$

7. pouca diferenciação entre subhorizontes.

Baseando-se nestes critérios, na cor e nos teores de ferro do ataque sulfúrico são reconhecidos atualmente no Brasil sete tipos de Latossolos (CAMARGO et al., 1987; OLIVEIRA et al., 1992): Ferrífero (LF), Roxo (LR), Vermelho-Escuro (LE), Vermelho-Amarelo (LV), Amarelo (LA), Bruno (LB), Vermelho-Amarelo variação Una (LU). Mais recentemente, foi discutida a criação do Latossolo Pálido (LP) (CARVALHO FILHO et al., 1993) cuja definição e implantação no sistema brasileiro de classificação ainda depende de mais estudos. Quando estes Latossolos apresentam horizonte A espesso e rico em matéria orgânica, fato mais comum nos LV, LB, LU, LR, LF e LV, são denominados Latossolos Húmicos (LH). As principais características bem como a distribuição geográfica destes solos são descritas a seguir.

\section{TIPOS DE LATOSSOLOS RECONHECIDOS NO BRASIL}

\section{Latossolo Ferrífero}

Compreende solos minerais, não hidromórficos, profundos, bem a acentuadamente drenados, de coloração avermelhada, com altos teores de $\mathrm{Fe}_{2} \mathrm{O}_{3}$ obtidos pelo ataque sulfúrico (>35\% - Quadro 1), que se desenvolvem a partir de rochas ricas em ferro (itabiritos), principalmente em áreas de relevo movimentado e rampas de colúvio no Quadrilátero Ferrífero (CAMARGO, 1982; CURI, 1983; OLIVEIRA et al.; 1983; SANTOS, 1993).

Caracterizam-se, ainda, pela elevada atração ao magneto (magnetização) ditada pela presença de magnetita nas frações silte e areia, e maghemita na fração argila (CURI, 1983; RESENDE et al., 1988). Postula-se (EMBRAPA-SNLCS, 1988), que a hematita presente nos Latossolos Ferríferos é herdada do próprio material de origem e parece ser mais resistente à goethitização, mesmo em ambiente bastante úmido e de grande umidade relativa, como na área de ocorrência destes solos no Quadrilátero Ferrífero. Em razão disso, pelo grande poder pigmentante da hematita (RESENDE, 1976), os Latossolos Ferríferos apresentam uma coloração avermelhada forte.

$\mathrm{Na}$ constituição mineralógica da fração argila predominam hematita, maghemita, gibbsita, além de pequenas proporções de caulinita, goethita, anatásio e rutilo (CURI, 1983; ANTONELLO et al., 1988; KÄMPF et al., 1988; SANTOS, 1993; KER \& SCHAEFER, 1995).

A constituição dominantemente oxídica, praticamente sem filossilicatos confere a estes solos uma estrutura granular fortemente desenvolvida, uma baixa capacidade de troca catiônica e permeabilidade excessiva. Além disso, é comum apresentarem nos horizontes subsuperficiais, $\mathrm{pH}$ em $\mathrm{H}_{2} \mathrm{O}$ menor que $\mathrm{pH}$ em $\mathrm{KCl}$, sugerindo solos eletropositivos, portanto de maior afinidade aniônica (Quadro 1).

São solos de baixíssima fertilidade natural (Quadro 1). Apresentam baixa CTC (valor T) apesar do $\mathrm{pH}$ elevado. Este último fato tem sido também verificado em outros Latossolos argilosos e oxídicos. Esta característica foi denominada por MATTSON (1932) como "intemperismo isoelétrico" e refere-se à tendência do $\mathrm{pH}$ do solo acompanhar o $\mathrm{pH}$ do ponto de carga zero (PCZ) dos óxidos de ferro e mesmo alumínio à medida que intensifica a lixiviação tornando a solução cada vez menos concentrada.

A baixa fertilidade limita sobremaneira a sua utilização agrícola. Assim, quando não encontram-se sob vegetação natural (campo cerrado altimontano), são utilizados com reflorestamentos de eucalipto, com resultados aquém das

Quadro 1: Características químicas do horizonte B de alguns Latossolos Ferríferos descritos no Brasil.

Table 1: Chemical characteristics of B horizons of some Ferriferous Latosols in Brazil.

\begin{tabular}{|c|c|c|c|c|c|c|c|c|c|c|c|c|}
\hline \multirow{3}{*}{ Localização } & \multicolumn{12}{|c|}{ Características Químicas } \\
\hline & ---- & H ---- & $\mathrm{Mg}^{++}$ & $\mathrm{Al}^{+++}$ & $\mathrm{H}^{+}$ & s & $\mathbf{T}$ & $\mathrm{SiO}_{2}$ & $\mathrm{Al}_{2} \mathrm{O}_{3}$ & $\mathrm{Fe}_{2} \mathrm{O}_{3}$ & $\mathrm{TiO}_{2}$ & $\mathbf{K i}$ \\
\hline & $\mathrm{H}_{2} \mathrm{O}$ & $\mathrm{KCl}$ & - cm & $\mathrm{c}^{/ \mathrm{kg}}$ & . & ------ & 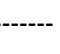 & . & ----- da & kg --- & - & \\
\hline Nova Lima - MG (1) & 6,2 & 6,4 & 0,1 & 0,0 & 1,2 & 0,2 & 1,4 & 1,0 & 17,7 & 59,7 & 2,31 & 0,10 \\
\hline Nova Lima - MG (1) & 6,2 & 5,9 & 0,2 & 0,0 & 0,6 & 0,2 & 0,8 & 1,3 & 15,9 & 64,2 & 1,99 & 0,14 \\
\hline Nova Lima - MG (2) & 6,2 & 6,7 & 0,2 & 0,0 & 1,2 & 0,2 & 1,4 & 2,1 & 21,4 & 55,5 & 1,25 & 0,17 \\
\hline Guanhães - MG (3) & - & - & 0,1 & - & - & - & - & 0,22 & 8,93 & 74,5 & - & 0,04 \\
\hline
\end{tabular}

(1) OLIVEIRA et al., 1983; (2) KER \& SCHAEFER, 1995 - Latossolo Ferrífero Petroplíntico; (3) SANTOS, 1993. 
expectativas de produtividade em relação a outros Latossolos de áreas próximas $^{(2)}$. Ainda que isto não seja bem explicado, especula-se que além da fertilidade natural e a quase ausência de silicatos conferindo baixa CTC, este solo apresente um comportamento hídrico (baixa retenção de umidade) diferenciada dos Latossolos de textura similar, em razão de sua constituição dominantemente hematítica.

É comum nestes solos, ainda, a presença de concreções ferruginosas dando à textura a condição de cascalhenta subsuperficialmente (Oliveira et al., 1983) ou mesmo constituindo verdadeiro corpo concrecionário (canga ou couraça ferruginosa) contínuo ou fragmentado, por onde permeiam pequenas quantidades de solo, dando origem aos Latossolos Ferríferos Petroplínticos (Ker \& Schaefer, 1995).

É muito discutido entre os pedólogos brasileiros o fato de se continuar separando os Latossolos Ferríferos (LF) dos Latossolos Roxos (LR). Os favoráveis à junção das duas classes destacam que a nível de campo a distinção nem sempre é fácil. Aqueles contra, postulam que os Latossolos Ferríferos apresentam teores de $\mathrm{Fe}_{2} \mathrm{O}_{3}$ muito elevados, alta densidade das partículas e baixos teores de determinados elementos traços com afinidade geoquímica ao ferro ( $\mathrm{Zn}, \mathrm{Ni}$ e $\mathrm{Cu}$ ). A distinção entre estes solos (LF e LR) ainda persiste e, além dos critérios anteriormente assinalados, talvez um dos melhores parâmetros de separação entre eles, ainda seja a relação $\mathrm{Fe}_{2} \mathrm{O}_{3} / \mathrm{TiO}_{2}$, geralmente maior que 25 nos LF, baseando-se nos perfis até então analisados (Quadro 1).

As relações moleculares $\mathrm{SiO}_{2} / \mathrm{Al}_{2} \mathrm{O}_{3}(\mathrm{Ki})$ e $\mathrm{SiO}_{2} /$ $\mathrm{Al}_{2} \mathrm{O}_{3}+\mathrm{Fe}_{2} \mathrm{O}_{3}(\mathrm{Kr})$ destes Latossolos são muito baixas, em geral menores que 0,2 (Oliveira et al., 1983). Isso é resultante da pobreza do material de origem em componentes contendo sílica e mesmo alumínio, em se comparando com aqueles contendo ferro. Dessa forma, estas duas relações não são boas indicadoras de grau de evolução desses solos, uma vez que mesmo solos pouco evoluídos (Cambissolos) desenvolvidos de materiais ricos em ferro apresentam baixos valores de $\mathrm{Ki}$ e $\mathrm{Kr}$ (amostras extras no 511 e 512 de Oliveira et al., 1983).

\section{Latossolo Roxo}

Inicialmente reconhecidos como Terra Roxa Legítima (BRASIL, 1960), os atuais Latossolos Roxos referem-se a solos minerais, profundos, bem a acentuadamente drenados de coloração vermelhoarroxeada, com matizes mais avermelhadas que 4YR, com altos teores de $\mathrm{Fe}_{2} \mathrm{O}_{3}$ do ataque sulfúrico (18 < $\left.\mathrm{Fe}_{2} \mathrm{O}_{3}<47^{(3)}\right)$, cuja distribuição geográfica encontra-se associada à presença de rochas efusivas básicas, metabasitos e tufitos em expressivas áreas do Rio Grande do Sul, Paraná, Santa Catarina, São Paulo, Minas Gerais, Mato Grosso, Mato Grosso de Sul e Goiás (Figura 1).

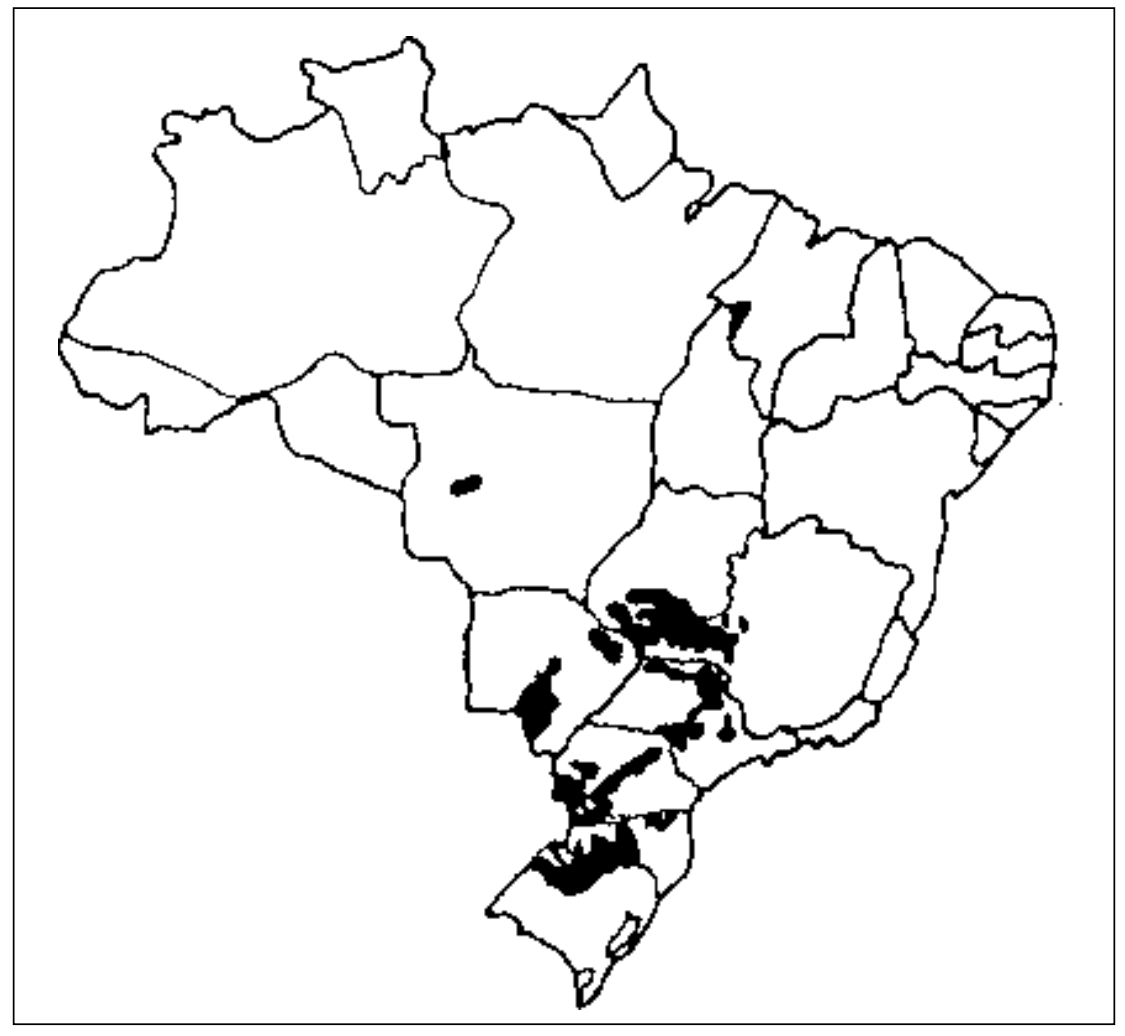

Figura 1: Representação esquemática da distribuição de Latossolos Roxos no Brasil. Fonte: Mapa de Solos do Brasil - EMBRAPA-SNLCS, 1981.

Figure 1: Schematic representation of Dusky-Red Latosols in Brazil. Source: General soil map of Brazil, 1981.

(2) Comunicação pessoal do Dr. Antônio Sérgio Fabres - CENIBRA - Celulose Nipobrasileira - Ipatinga - MG.

(3) Limite superior baseado em dado de literatura, referente a solo desenvolvido de tufito. 
Além das características mencionadas acima, os Latossolos Roxos apresentam elevada magnetização, especialmente quando derivados de basalto e tufito. Fogem a esta tendência alguns LR derivados de outros materiais de origem, ainda que de natureza básica (Schaefer, 1991; Ker et al., 1993; Ker, 1995). Nestes últimos casos, a pobreza do material de origem em magnetita (Guimarães, 1947) parece ser a explicação mais convincente para a baixa magnetização apresentada pelo solo.

Os Latossolos Roxos são, em sua grande maioria, de textura argilosa ou muito argilosa, condição esta ditada pela própria pobreza em quartzo do material de origem. Algumas exceções, entretanto, são constatadas: um LR de Uberaba, originado de arenito com influência de rochas máficas (EMBRAPA/EPAMIG, 1982); e LR desenvolvidos a partir de diabásio no Pólo Trombetas PA (EMBRAPA-SNLCS, 1984), ambos com textura média $(15<\%$ argila $<35)$.

Quanto à mineralogia, pode-se dizer que na fração grosseira predomina a magnetita, magnetita intercrescida de ilmenita e quartzo; este último em pequenas proporções. $\mathrm{Na}$ fração argila constata-se principalmente caulinita, gibbsita e hematita e mesmo maghemita, goethita e vermiculita com hidroxi entrecamadas (Moura Filho, 1970; Resende, 1976; Motch,
1977; Souza, 1979; Curi, 1983; Santana; 1984; Palmiere, 1986; Resende et al., 1988; Ker, 1995; Bognola, 1996).

A proporção entre os componentes mineralógicos da fração argila dos Latossolos Roxos pode variar de local para local, a depender da intensidade do intemperismo sobre estes solos. De maneira geral, entretanto, os solos mais cauliníticos, a inferir-se pelo $\mathrm{Ki}$, e talvez com maiores proporções de vermiculita com hidroxi entre-camadas, encontrem-se no Rio Grande do Sul (BRASIL, 1973) Mato Grosso do Sul (BRASIL 1971) e Paraná (EMBRAPA/IAPAR, 1984). No Estado do Paraná, baseando-se nos dados de cerca de 30 perfis (EMBRAPA/IAPAR, 1984; EMBRAPA-SBCS, 1988) também parece predominar Latossolos Roxos mais cauliníticos, muito embora já ocorram perfis com Ki igual a 0,6, sugerindo participação expressiva de gibbsita. De São Paulo para o Brasil Central, estes solos tendem a tornar-se cada vez mais intemperizados, portanto, mais gibbsíticos, não sendo raros solos com Ki da ordem de 0,2 (Quadro 2).

Os teores de titânio são variáveis e normalmente elevados (Quadro 2). Isso se traduz numa relação $\mathrm{Fe}_{2} \mathrm{O}_{3} /$ $\mathrm{TiO}_{2}$ sempre menor que $25 \%$, diferenciado-os dos Latossolos Ferríferos.

Quanto à fertilidade natural, têm sido constatados

Quadro 2 - Resultados da relação molecular $\mathrm{SiO}_{2} / \mathrm{Al}_{2} \mathrm{O}_{3}(\mathrm{Ki}), \mathrm{Fe}_{2} \mathrm{O}_{3}$, $\mathrm{TiO}_{2}$ e $\mathrm{P}_{2} \mathrm{O}_{5}$ obtidos pelo ataque sulfúrico de horizonte $B$ de Latossolos Roxos derivados de basalto de diferentes regiões do Brasil.

Table 2: $\mathrm{SiO}_{2} / \mathrm{Al}_{2} \mathrm{O}_{3}(\mathrm{Ki})$ molecular ratio, $\mathrm{Fe}_{2} \mathrm{O}_{3}, \mathrm{TiO}_{2}$ and $\mathrm{P}_{2} \mathrm{O}_{5}$ obtained by the sulfuric atack in $\mathrm{B}$ horizons of Dusky-Red Latosols in Brazil, developed from basaltic rocks.

\begin{tabular}{cccccc}
\hline Classificação & Localização & $\mathbf{K i}$ & $\mathbf{F e}_{\mathbf{2}} \mathbf{O}_{\mathbf{3}}$ & $\mathrm{Ti}_{\mathbf{2}} \mathbf{O}$ & $\mathbf{P}_{\mathbf{2}} \mathbf{O}_{\mathbf{5}}$ \\
& & & ------------- dag/kg----------- \\
\hline LR distrófico (1) & Erechim - RS & 2,09 & 22,3 & 4,18 & 0,18 \\
LR álico (2) & Mangueirinha - PR & 1,96 & 25,2 & 3,89 & - \\
LR distrófico (1) & Santo Ângelo - RS & 1,93 & 22,7 & 3,84 & 0,21 \\
LR distrófico (3) & Dourados - MS & 1,85 & 27,0 & 3,77 & 0,09 \\
LR distrófico (2) & Medianeira - PR & 1,75 & 19,6 & 2,27 & - \\
LR distrófico (2) & Londrina - PR & 1,46 & 22,0 & 4,02 & - \\
LR eutrófico (4) & Ituverava - SP & 1,34 & 24,9 & 5,02 & 0,28 \\
LR distrófico (6) & Bonfim Paulista - SP & 1,01 & 32,4 & 8,50 & - \\
LR distrófico (5) & Pirajuba - MG & 0,95 & 36,5 & 6,11 & - \\
LR distrófico (5) & Canápolis - MG & 0,71 & 27,7 & 6,65 & - \\
LR distrófico (2) & Cascavel - PR & 0,64 & 28,2 & 4,18 & - \\
LR distrófico (4) & Ribeirão Preto - SP & 0,54 & 33,8 & 7,16 & 0,15 \\
LR distrófico (7) & Cravinhos - SP & 0,41 & 35,6 & 5,07 & 0,14 \\
LR distrófico (8) & Rio Verde - GO & 0,35 & 25,5 & 5,52 & 0,18 \\
LR distrófico (8) & Diamantino - MT & 0,31 & 23,3 & 1,94 & 0,04 \\
LR distrófico (7) & Jardinópolis - SP & 0,21 & 30,0 & 6,88 & 0,15 \\
\hline
\end{tabular}

(1) BRASIL, 1973; (2) EMBRAPA/IAPAR, 1984; (3) BRASIL, 1971; (4) BRASIL, 1960; (5) EMBRAPA/EPAMIG, 1982; (6) OLIVEIRA \& MENCK, 1984; (7) EMBRAPA SBCS, 1988; 8/ EMBRAPA - SNLCS, 1975. 
desde solos muito férteis (eutróficos) até muito pobres quimicamente (álicos ou distróficos) não obstante originarem-se de rochas ricas em alguns elementos como cálcio e magnésio (basaltos, além de gabros, diabásios, tufitos etc). Contudo, em geral, a reserva ou fertilidade potencial dos LR realmente parece ser maior que a dos demais Latossolos, principalmente no que diz respeito a fósforo total e alguns elementos traços como $\mathrm{Mn}, \mathrm{Ni}, \mathrm{Cu}, \mathrm{Zn}$ e $\mathrm{Co}$, alguns deles essenciais às plantas (Mn, Zn e Cu) e importante na alimentação animal (Co) (Quadro 3).

A ocorrência de LR eutróficos em áreas relativamente úmidas parece retratar que a lixiviação não parece tão intensa como se esperaria pela boa drenagem. A reciclagem pode estar contribuindo para isso, ou mesmo a preservação de cátions nos microagregados, conforme constatado por Moura Filho \& Buol (1976). de tufitos vulcânicos da formação Mata da Corda (Cretáceo) no Alto Paranaíba - MG (Carmo, 1977). A porosidade da rocha facilita o intemperismo e a lixiviação, originando LR distróficos mesmo em áreas onde o rejuvenescimento parece intenso.

Observa-se (Figura 1) a ocorrência pouco expressiva de LR em estados do norte do país, muito embora levantamentos mais detalhados em determinadas áreas registrem sua ocorrência (EMBRAPA-SNLCS, 1984).

\section{Latossolo Vermelho-Escuro}

Formados a partir de uma grande diversidade de materiais de origem, os Latossolos de coloração avermelhada com teores de ferro obtidos pelo ataque sulfúrico entre 8 e $18 \%$ são denominados VermelhoEscuros (LE). Apesar do limite mínimo de $\mathrm{Fe}_{2} \mathrm{O}_{3}$ estabelecido, vários são os solos de cor avermelhada reconhecidos, e com teores menores que $8 \%$, indicando

Quadro 3: Teores de cobalto, níquel, cobre, zinco e manganês provenientes do ataque ácido total da terra fina seca ao ar de horizonte $B$ de Latossolos brasileiros.

Table 3: $\mathrm{Co}, \mathrm{Ni}, \mathrm{Cu}, \mathrm{Zn}$ and $\mathrm{Mn}$ amounts after chemical attack of fine-earth of

$B$ horizons from Brazilian Latosols.

\begin{tabular}{ccccccccc}
\hline \multirow{2}{*}{ Solo } & Local & Material de Origem & Co & $\mathbf{N i}$ & $\mathbf{C u}$ & Zn & Mn & Total \\
\cline { 3 - 8 } & & & & \multicolumn{7}{c}{$\mathbf{m g} / \mathbf{k g}$} \\
\hline LR (K1) & Cravinhos - SP & Basalto & 95 & 69 & 174 & 102 & 791 & 1231 \\
LR (K2) & Ribeirão Preto - SP & Basalto & - & 56 & 178 & 122 & 1100 & 1456 \\
LR (K17) & Silvânia - GO & Anfibolito & - & 50 & 52 & 72 & 338 & 215 \\
LR (K23) & Catalão - GO & Ultrabásicas & - & 73 & 96 & 110 & 1712 & 1991 \\
LR (K26) & Dourados - MS & Basalto & 91 & 66 & 365 & 120 & 929 & 1571 \\
LR (K29) & Patos - MG & Tufito & - & 327 & 242 & 140 & 2917 & 3626 \\
LF (K30) & Nova Lima - MG & Itabirito & - & 0 & 21 & 33 & 293 & 347 \\
LE (K16) & Piracicaba - SP & Sed. Argilosos & 5 & 13 & 43 & 40 & 164 & 265 \\
LV (K8) & Silvânia - GO & Sed. Argilosos & - & 15 & 36 & 40 & 193 & 284 \\
LV (K11) & Abre Campo - MG & Gnaisse & 22 & 36 & 45 & 42 & 209 & 354 \\
LA (K20) & Acará - PA & Sed. Barreiras & 19 & 11 & 16 & 43 & 96 & 185 \\
\hline
\end{tabular}

Fonte: KER, 1995

O sucesso da agricultura nas áreas de domínio dos Latossolos Roxos (Planalto Rio Grandense, Norte Paranaense, áreas de São Paulo com destaque para a região de Ribeirão Preto, Guaíra etc, Sudoeste Goiano, região de Dourados - MS e Tangará da Serra - MS), parece confirmar a grande potencialidade agrícola destes solos, quer pela fertilidade natural, facilidade e resposta à correção da fertilidade quando for o caso e, ainda, pela possibilidade ampla de mecanização e mesmo de irrigação em alguns locais.

Embora tendam a ocorrer em áreas de relevo mais suave, tem sido mencionada sua ocorrência em áreas de topografia mais movimentada. É o caso de LR em relevo ondulado e forte ondulado de áreas de influência a necessidade de reavaliação do limite inferior de $\mathrm{Fe}_{2} \mathrm{O}_{3}$ para esta classe.

Desenvolvem-se a partir de arenitos, calcários, gnaisses e mesmo de materiais retrabalhados e préintemperizados referentes à cobertura detrito-laterítica, entre outros materiais. Em razão disso, são de fertilidade e textura muito variadas, sendo encontrados solos distróficos, álicos e eutróficos e de textura que vai de franco arenosa a muito argilosa, constituindo-se, pois, em uma classe relativamente heterogênea nestes aspectos (Quadro 4).

Encontram-se amplamente distribuídos pelo território nacional com destaque para os estados do Mato Grosso do Sul, Goiás, Minas Gerais, Paraná, São 
Quadro 4 : Características químicas e físicas de horizontes B de Latossolos Vermelho-Escuros de diferentes regiões do Brasil.

Table 4: Chemical and physical chacracteristics of B horizon from Dark-Red Latosols in Brazil.

\begin{tabular}{|c|c|c|c|c|c|c|c|c|c|c|}
\hline \multirow[t]{3}{*}{ Local } & \multirow{3}{*}{$\begin{array}{c}\text { Material } \\
\text { de Origem }\end{array}$} & \multicolumn{9}{|c|}{ Características Físicas e Químicas } \\
\hline & & \multirow{2}{*}{$\begin{array}{c}\text { Arg. } \\
\%\end{array}$} & $\mathrm{Fe}_{2} \mathrm{O}_{3}$ & $\mathrm{Ti}_{2} \mathrm{O}$ & $\mathrm{P}_{2} \mathrm{O}_{5}$ & \multirow[t]{2}{*}{$\mathrm{Ki}$} & \multicolumn{2}{|c|}{$\mathrm{pH}$} & $\mathrm{v}$ & $\mathrm{m}$ \\
\hline & & & \multicolumn{3}{|c|}{ - } & & $\mathrm{H}_{2} \mathrm{O}$ & $\mathrm{KCl}$ & \multicolumn{2}{|c|}{ - } \\
\hline Iguatemi - MS (1) & Arenito & 18 & 3,3 & 0,61 & 0,02 & 2,06 & 5,3 & 4,4 & 14 & 75 \\
\hline Ponta Porã - MS (1) & Arenito & 27 & 5,5 & 0,95 & 0,02 & 1,65 & 5,4 & 4,2 & 13 & 75 \\
\hline Paranavaí - PR (2) & Aren+basalto & 41 & 5,9 & 0,81 & - & 2,03 & 5,1 & 4,0 & 18 & 69 \\
\hline P. Missões - RS (3) & Aren+basalto & 55 & 10,3 & 1,52 & 0,09 & 1,97 & 4,8 & 3,8 & 8 & 83 \\
\hline S.J. Del Rei - MG (4) & Micaxisto & 65 & 14,7 & 1,20 & 0,02 & 0,57 & 4,4 & 6,1 & 15 & 33 \\
\hline Rondonópolis - MT (5) & Sed. Terc. & 71 & 8,1 & 0,84 & 0,05 & 1,16 & 5,9 & 4,7 & 12 & 40 \\
\hline Janaúba - MG (6) & Calcário & 71 & 9,6 & 0,35 & 0,04 & 1,93 & 5,6 & 4,6 & 83 & 0 \\
\hline Brasília - DF (7) & Sed. Terc. & 77 & 15,5 & 0,72 & 0,04 & 0,51 & 6,1 & 6,4 & 40 & 0 \\
\hline P. Murtinho - MS (1) & Sed. Argil. & 81 & 9,7 & 0,71 & 0,03 & 1,84 & 5,5 & 4,2 & 14 & 73 \\
\hline Pinheiros - ES (8) & Barreiras & 57 & 5,1 & 0,86 & 0,02 & 1,96 & 6,8 & 5,6 & 86 & 0 \\
\hline
\end{tabular}

(1) BRASIL, 1971; (2) EMBRAPA/IAPAR, 1984; (3) BRASIL, 1973; (4) CHAGAS, 1994; (5) EMBRAPA-CPP, 1975;

(6) EMBRAPA-SNLCS, 1979; (7) CAVALCANTI 1977; (8) EMBRAPA - SNLCS, 1978

Paulo, Mato Grosso e Rio Grande do Sul (Figura 2). Observa-se sua pouca ocorrência em alguns estados do norte e do nordeste. Levantamentos mais detalhados em alguns locais do domínio Amazônico têm, entretanto, revelado a ocorrência destes solos.

De forma dominante, tendem a ocupar áreas de topografia plana ou suavemente ondulada, como aquelas dos amplos chapadões do Brasil Central, e constituemse juntamente com os Latossolos Roxos e VermelhoAmarelos, uma das principais classes de solos utilizadas com agricultura tecnificada, destacando-se soja, trigo, milho, feijão, café etc.

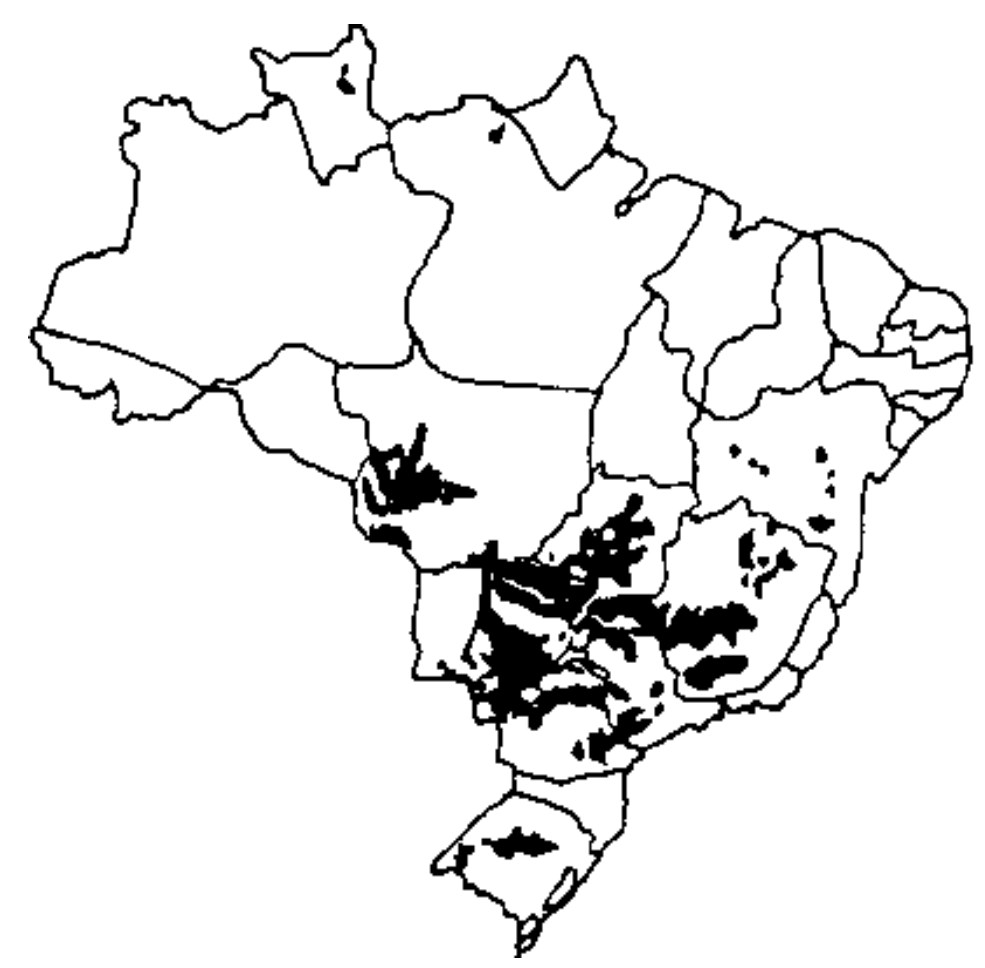

Figura 2: Representação esquemática da distribuição de Latossolos Vermelho-Escuros no Brasil.

Figure 2: Distribution of DarkRed Latosols in Brazil. 
Ainda que a mineralogia básica da fração argila seja constituída principalmente de caulinita, gibbsita, goethita e hematita, a proporção entre estes componentes é bastante variável, podendo ocorrer LE extremamente intemperizados (oxídicos), inclusive eletropositivos em subsuperfície (comuns no Planalto Central) até aqueles mais cauliníticos em outras áreas do Brasil (Quadro 4).

Em regiões mais secas (norte de Minas Gerais, IrecêBA etc), muitos solos avermelhados, profundos, de morfologia tipicamente latossólica e desenvolvidos de calcário, apresentam atividade de argila superior àquela requerida pela classe $\left(<13 \mathrm{cmol}_{\mathrm{c}} / \mathrm{kg}\right.$ de argila, após correção para carbono), intermediando-se para Cambissolos. Tem sido observado nestas e em outras áreas de calcário, LE com blocos subangulares argilosos grandes, com superfície externa brilhosa sugerindo cerosidade. Especula-se que tais blocos sejam herança do próprio material de origem, a inferir-se pela sua compacidade, pela manutenção do bandeamento da rocha e ausência de cerosidade interna.

Além dos menores teores de $\mathrm{Fe}_{2} \mathrm{O}_{3}$, os Latossolos Vermelho-Escuros diferem-se dos Roxos pelas menores: atração pelo magneto; reserva em elementos traços situações topográficas semelhantes. Na região fisiográfica dos Campos das Vertentes, em Minas Gerais, Chagas (1994) atribuiu esta ocorrência à inclinação mais verticalizada (Figura 3) dos estratos pelíticos do Grupo Andrelândia e São João Del Rei, favorecendo a drenagem interna e, consequentemente, a gênese de hematita, originando Latossolo VermelhoEscuro. Nos estratos mais horizontalizados a movimentação da água é restringida, o que resulta em regime hídrico mais úmido, favorecendo a gênese da goethita, formando solos amarelados caracterizados como LU.

\section{Latossolo Vermelho-Amarelo}

Com a maior e mais ampla distribuição geográfica no Brasil (Figura 4) dentre os Latossolos, aqueles de coloração amarelada, refletindo o amplo predomínio de goethita em relação à hematita, apresentando teores de $\mathrm{Fe}_{2} \mathrm{O}_{3}$ entre 7 e $11 \%$, quando de textura argilosa ou muito argilosa (EMBRAPA-SNLCS, 1988), ou com relação $\mathrm{Al}_{2} \mathrm{O}_{3} / \mathrm{Fe}_{2} \mathrm{O}_{3}>3,14$ quando de textura média (Bennena \& Camargo, 1964) são denominados Latossolos Vermelho-Amarelos.

Os Latossolos Vermelho-Amarelos são muito

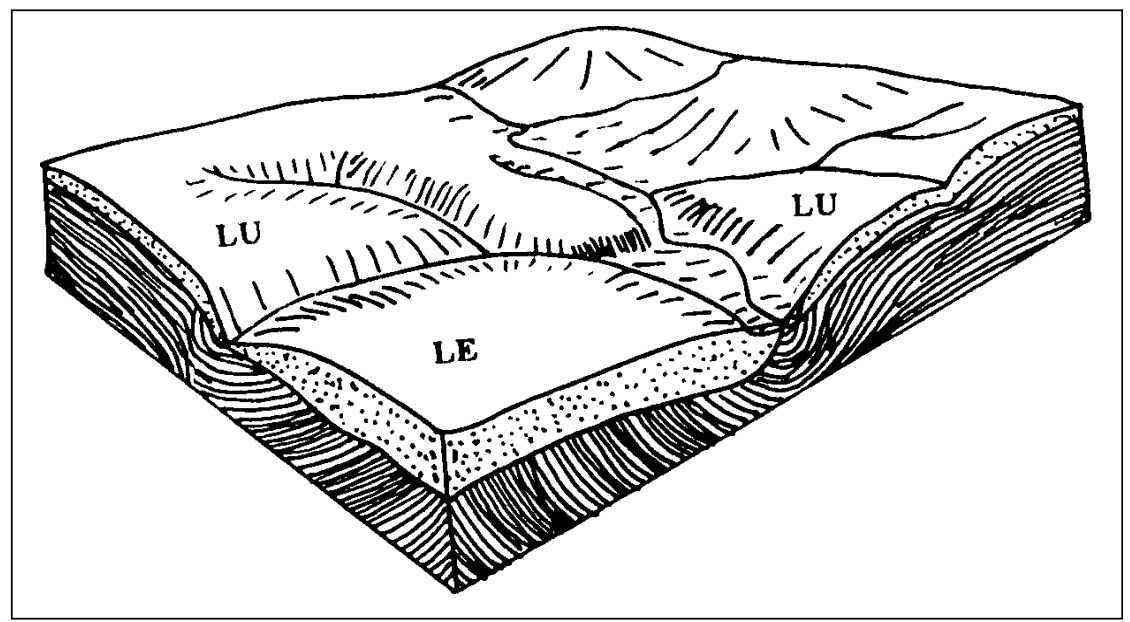

Figura 3: Efeito da orientação dos estratos de rochas pelíticas dos Grupos Andrelândia e São João Del Rei na formação de LE e LU na Região Fisiográfica dos Campos das Vertentes - MG. Fonte: CHAGAS, 1994.

Figure 3: Effect of strata orientation of pellitic rocks of Andrelândia and S. J. del Rey Groups on the formation of $L E$ and $L U$ in the Campos das Vertentes - MG.

como cobre, níquel, cobalto e zinco (Ker et al., 1993; Ker, 1995), quantidade de $\mathrm{P}_{2} \mathrm{O}_{5}$ total (Quadro 4). Valores médios de $0,06 \%$ de $\mathrm{P}_{2} \mathrm{O}_{5}$ no horizonte $\mathrm{A}$ de mais de 100 perfis catalogados, contra $0,16 \%$ para o mesmo horizonte de cerca de 30 perfis de LR indicam reservas, nada desprezíveis, nos primeiros vinte centímetros, da ordem de 1540 e $3520 \mathrm{~kg}$ de $\mathrm{P}_{2} \mathrm{O}_{5}$ por hectare, respectivamente para $\mathrm{LE}$ e $\mathrm{LR}$, considerando ambos com densidade aparente de $1,1 \mathrm{~g} / \mathrm{cm}^{3}$.

É comum em alguns locais da paisagem brasileira a ocorrência de Latossolos avermelhados (LE) lado a lado com aqueles amarelados (LU - Latossolo VermelhoAmarelo Variação Una, descrito posteriormente), em variáveis quanto à fertilidade natural (predominantemente distróficos e álicos e, mais raramente, eutróficos, sobretudo na região semi-árida brasileira); textura (desde $15 \%$ até mais de $80 \%$ de argila); relevo de ocorrência, sendo encontrados em áreas que variam do relevo plano (chapadões) ao montanhoso (45\% < declividade $<75 \%$ ), como alguns segmentos do domínio dos mares dos morros.

\section{Latossolo Amarelo}

Embora o nome Latossolo Amarelo tenha sido empregado desde a década de cinquenta para alguns Latossolos do Rio de Janeiro e, do então, Distrito 


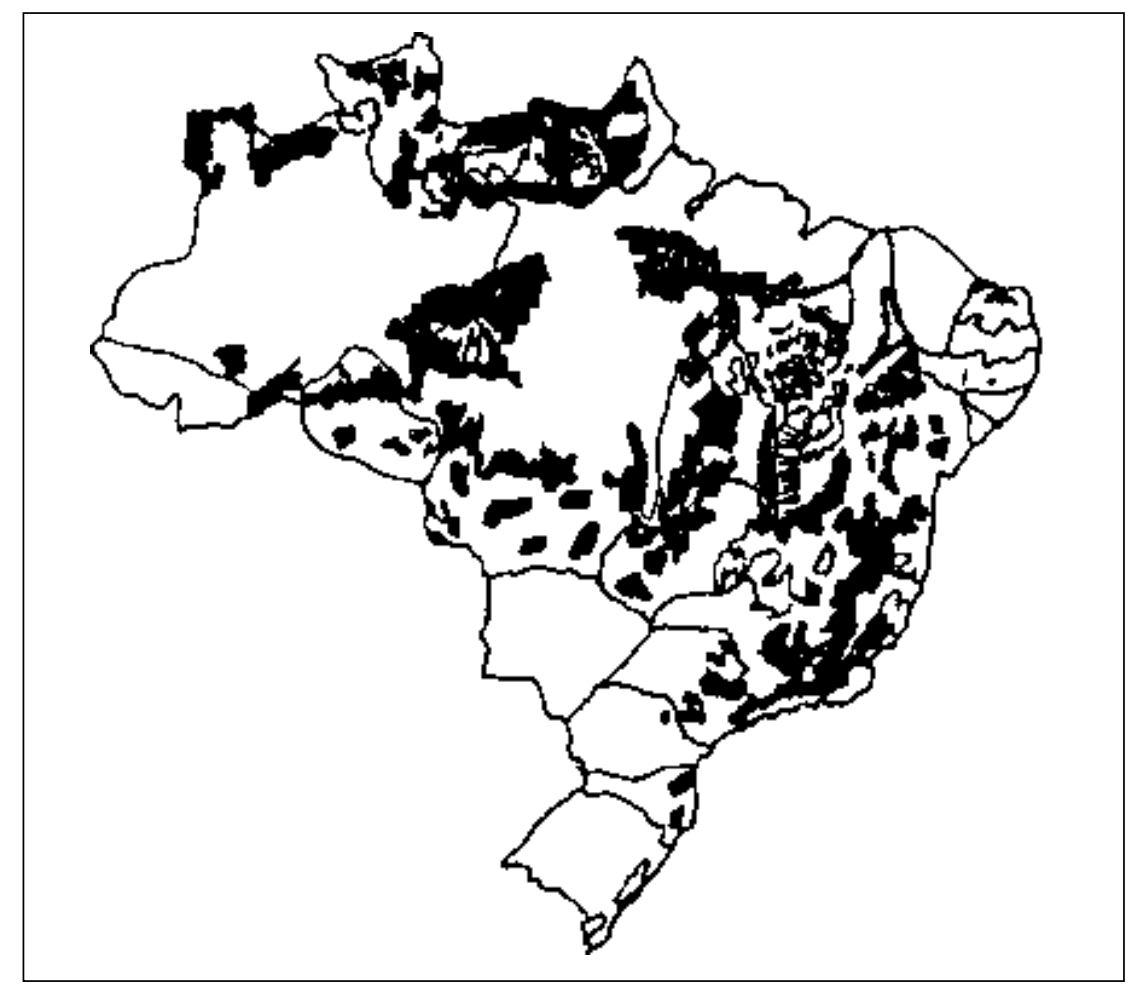

Figura 4: Representação esquemática da distribuição de Latossolos Vermelho-Amarelos no Brasil. Fonte: Mapa de Solos do Brasil (EMBRAPA - SNLCS, 1981).

Figure 4: Distribution of Red-Yellow Latosols in Brazil. Source: General soil map of Brazil, (EMBRAPA - SNLCS, 1981)

Federal, fora do domínio dos tabuleiros costeiros, os solos atualmente reconhecidos como Latossolos Amarelos (LA), tiveram como conceito de partida os "Kaolinitic Yellow Latosols" de solos amazônicos estudados por SOMBROEK (1966).

Os Latossolos Amarelos (LA) encontram-se espalhados em muitas áreas do Brasil. Sua maior expressividade e continuidade de área encontra-se nos platôs litorâneos e amazônicos (Figura 5), onde normalmente desenvolvem-se a partir de sedimentos do Grupo Barreiras (Plio-pleistoceno) e Formação Alter do Chão (Cretáceo).

Englobam solos profundos, amarelos, com matizes do horizonte B entre 7,5YR e 10YR, cauliníticos,

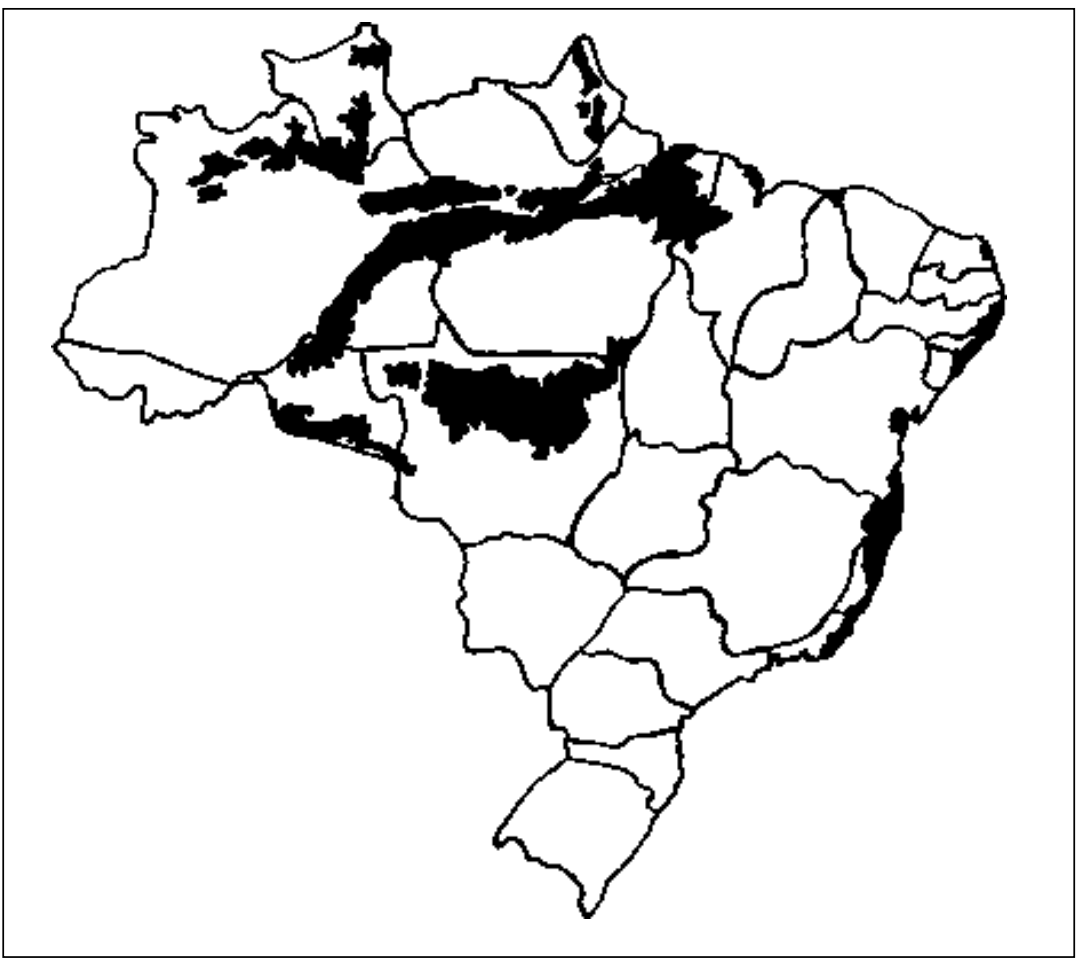

Figura 5: Representação esquemática da distribuição de Latossolos Amarelos no Brasil. Fonte: Mapa de Solos do Brasil (EMBRAPA - SNLCS, 1981).

Figure 5: Distribution of Yellow Soils in Brazil. Source: General soil map of Brazil, (EMBRAPA SNLCS, 1981) 
Sombroek (1966) cita quantidades de caulinita superiores a $80 \%$ na fração argila de LA amazônicos), de textura com extremos de argila que vão de 15 a $95 \%$ (Oliveira et al., 1992; Rodrigues 1996). Os teores de $\mathrm{Fe}_{2} \mathrm{O}_{3}$ do ataque sulfúrico situam-se entre 1,5 a $7 \%$ e o $\mathrm{Ki}$ é normalmente maior que 1,5 , refletindo sua natureza caulinítica. Os baixos teores de $\mathrm{Fe}_{2} \mathrm{O}_{3}$ $(<7 \%)$ e a ausência virtual de gibbsita, parecem ser as causas principais da estrutura em blocos subangulares fracamente desenvolvida e de pouca estabilidade em água (Bennema \& Camargo, 1979).

Uma das características mais conspícuas dos Latossolos Amarelos é a coesão ${ }^{(4)}$ manifestada entre os horizontes A e B, fato este que levou a classificação destes solos, no passado, como Latossolo VermelhoAmarelo coeso em vários estados do país (Jacomine, 1996). Várias têm sido as proposições explicativas, e não exclusivas, para a manifestação desta coesão nos LA:

- ACHÁ-PANOSO (1976) destaca que as camadas endurecidas observadas em Latossolos Amarelos dos tabuleiros costeiros do Espírito Santo variam de poucos centímetros até cerca de 2 metros e que sua ocorrência deve-se ao entulhamento de partículas (argilas) oriundas dos horizontes superiores, as quais preencheriam poros (macro e micro), aumentando a densidade aparente tornando a camada muito coesa e compacta. Destaca, ainda, que os menores teores de ferro normalmente observados na camada endurecida poderiam contribuir para uma maior coesão;

- Baseando-se no fato de que estes solos coesos quando secos tornam-se friáveis quando úmidos, alguns autores propõem que esta característica peculiar dos LA e solos afins, deve-se mais ao arranjo das partículas em nível microscópico (UFV, 1984; Ferreira, 1988). Ou seja, como os LA apresentam baixas quantidades de óxidos de ferro (goethita no caso) e de alumínio (gibbsita), o ajuste face a face das partículas de caulinita seria favorecido, e responsável pelo seu endurecimento quando seco. As moléculas de água entrando entre as partículas de argila orientadas, reduziriam a coesão e os solos tornariam-se friáveis.

- Anjos (1985) e Fonseca (1986) propõem que a camada adensada, dos horizontes transicionais $\mathrm{AB}$ e/ ou BA e mesmo parte dos horizontes B a esses subjacentes, de Latossolos e Podzólicos Amarelos por eles estudados e representativos de tabuleiros costeiros do Rio de Janeiro, Espírito Santo, Bahia, Pernambuco, é herdada dos próprio sedimento que os originou (Barreiras). A causa do endurecimento, seria a compressão causada pelo peso estático da camada superior.

- Meirelles e Ribeiro (1995) destacam a participação decisiva de componentes orgânicos, notadamente os ácidos fúlvicos, na degradação do plasma (fração argila), liberando alumínio, ferro e, principalmente, sílica, têm papel preponderante na formação de horizontes coesos de solos de tabuleiro, na região de Cruz das Almas - BA. Esta afirmativa tem por base a constatação de teores de sílica, alumínio, ferro e ácidos fúlvicos mais elevados nos horizontes $\mathrm{AB}$ e $\mathrm{BA}$ de solos de tabuleiros da Bahia, em relação aos horizontes superiores e inferiores, bem como a evidência, via microscopia eletrônica de varredura, do preenchimento de poros por sílica.

A constatação de Meirelles e Ribeiro (1995) mencionada anteriormente, parece explicar o porque da tendência geral de maiores teores de argila dispersa em água nos horizontes superficiais e subsuperficiais coesos dos Latossolos e Podzólicos dos Tabuleiros (Quadro 5). Nos primeiros pela matéria orgânica, nos segundos, tanto pelos componentes orgânicos (ácidos fúlvicos) como pela sílica, ambos contribuindo para o abaixamento do PCZ, gerando mais cargas negativas e, consequentemente, maior dispersão. A não formação de fragipan em tais casos, possivelmente deva-se aos ainda elevados teores de argila, promovendo expansão e contração e inibindo a ação cimentante da sílica, ou mesmo alumínio e ferro (Ranson et al., 1987), ou ainda pelos teores relativamente baixos de sílica "amorfa".

Baseando-se nestas teorias, a manifestação da coesão parece melhor explicada pela associação do arranjo face a face e ação cimentante da sílica "amorfa" extraída com oxalato.

Observa-se (Quadro 5) diferenças muito claras entre Latossolos Amarelos de diferentes regiões. Enquanto o LA de Campos - RJ mostra-se com expressivas quantidades de argila dispersa em água até $97 \mathrm{~cm}$, além da densidade elevada e da classificação como coeso, o mesmo não ocorre com o LA de Manaus. Este último é muito argiloso e já no segundo horizonte a argila encontra-se praticamente toda floculada. É possível que no LA da Amazônia, o excesso de umidade não permita a manifestação do caráter coeso. Em alguns locais da Amazônia (Roraima ${ }^{(5)}$, por exemplo), onde o período seco é bem definido, a manifestação da coesão é também característica nos Latossolos Amarelos. Isso evidencia a necessidade de cuidado ao se tentar estabelecer generalizações sobre os Latossolos Amarelos de diferentes regiões.

\section{Latossolo Bruno}

Foram denominados Latossolos Brunos (LB) (Bennema \& Camargo, 1964) solos latossólicos de colorações brunadas e amareladas que ocorriam em regiões de altitudes, frias e úmidas de algumas localidades do país, como Vacaria-RS, Campos do Jordão, Apiaí e Itaré-SP, cujas características peculiares, além da cor, referiam-se à dureza e ao fendilhamento expressivos do solo quando seco, estrutura em blocos subangulares bem desenvolvida e horizonte A escuro e espesso, normalmente proeminente ou húmico.

Solos com características similares àquelas referidas acima foram posteriormente identificados em regiões de altitude de outros estados: Santa Catarina (UFSMSUDESUL, 1973), Paraná (EMBRAPA-IAPAR, 1984) e Minas Gerais (Oliveira et al., 1983; EMBRAPASNLCS, 1984; Rodrigues, 1984), cujo acúmulo de

(4) Coeso - significando duro ou tenaz, tem sido empregado para distinguir horizontes minerais subsuperficiais dos solos que se apresentam duros, muito duros e até extremamente duros quando secos (JACOMINE, 1996).

(5) Informação pessoal do professor Carlos Ernesto Schaefer, do Departamento de Solos - UFV. 
Quadro 5: Características físicas de Latossolos Amarelos de tabuleiros costeiros do Rio de Janeiro (Grupo Barreiras) e Amazonas (Formação Alter do Chão).

Table 5: Physical characteristics of Yellow Latosols from the coastal tablelands in Rio de Janeiro and Amazons.

\begin{tabular}{|c|c|c|c|c|c|c|c|c|}
\hline \multirow[b]{2}{*}{ Horiz. } & \multirow{3}{*}{$\begin{array}{l}\text { Prof } \\
(\mathrm{cm})\end{array}$} & \multicolumn{4}{|c|}{ Granulometria da TFSA } & \multirow[b]{2}{*}{ ADA } & \multirow[b]{2}{*}{ GF } & \multirow[b]{2}{*}{$\begin{array}{l}\text { Dap } \\
\text { g.cm }\end{array}$} \\
\hline & & AG & AF & SIL & ARG & & & \\
\hline \multicolumn{8}{|c|}{ LA - Campos - RJ (1) } & \\
\hline Ap & $0-11$ & 35 & 15 & 3 & 47 & 38 & 19 & 1,36 \\
\hline$A B$ & -36 & 33 & 14 & 3 & 50 & 43 & 14 & 1,45 \\
\hline BA & -52 & 30 & 14 & 3 & 53 & 46 & 13 & 1,38 \\
\hline Bw1 & -97 & 29 & 15 & 4 & 52 & 25 & 52 & 1,48 \\
\hline Bw2 & -125 & 30 & 15 & 3 & 52 & 0 & 100 & 1,48 \\
\hline Bw3 & -144 & 29 & 16 & 4 & 51 & 0 & 100 & 1,48 \\
\hline $\mathrm{BC}$ & -167 & 29 & 13 & 5 & 53 & 0 & 100 & 1,40 \\
\hline \multicolumn{9}{|c|}{ LA - Manaus - AM (2) } \\
\hline$A p$ & $0-8$ & 11 & 4 & 9 & 76 & 31 & 59 & - \\
\hline$A B$ & -22 & 9 & 3 & 8 & 80 & 0 & 100 & - \\
\hline Bw1 & -50 & 6 & 2 & 8 & 84 & 0 & 100 & - \\
\hline Bw2 & -125 & 5 & 2 & 5 & 88 & 0 & 100 & - \\
\hline Bw3 & -265 & 4 & 1 & 6 & 89 & 0 & 100 & - \\
\hline Bw4 & -350 & 3 & 1 & 6 & 90 & 0 & 100 & - \\
\hline
\end{tabular}

$\mathrm{AG}=$ areia grossa; $\mathrm{AF}=$ areia fina; $\mathrm{SIL}=$ silte; $\mathrm{ARG}=$ argila; $\mathrm{ADA}=$ argila dispersa em $\mathrm{H}_{2} \mathrm{O} ; \mathrm{GF}=$ grau de floculação; Dap = densidade aparente. Fonte: (1) EMBRAPA, 1995; (2) BARRETO, 1986.

dados, ainda que não muito expressivo, permitiu uma redefinição desta classe no início dos anos oitenta (Carvalho, 1982), conforme descreve-se a seguir.

Compreende solos minerais, não hidromórficos com horizonte Bw de coloração brunada ou amarelada dentro dos matizes 7,5YR e 10YR, textura argilosa ou muito argilosa, com horizonte $\mathrm{A}$ espesso, rico em matéria orgânica, normalmente proeminente ou húmico, derivados de rochas eruptivas básicas, intermediárias e alcalinas, e circunscritos a algumas regiões de altitude dos estados mencionados anteriormente, normalmente sob regime climático térmico údico.

Além destas características, aspectos como a sensação deslizante ou escorregadia quando se faz a avaliação textural ou mesmo ao se fazer penetrar uma faca no solo úmido e ao retirá-la observar certo umedecimento na lâmina, sugerindo propriedades tixotrópicas ${ }^{(6)}$, eram motivo de suspeita da presença de alofana para os solos brunos em geral (Latossolos, Cambissolos e Terras Brunas), mantendo, em consequência, correlação com Andisols. Esta hipótese não foi confirmada em vários estudos desenvolvidos nos solos brunos, inclusive Latossolos, de diferentes regiões do Brasil (Potter \& Kämpf, 1981; Rodrigues,
1984; Palmiere, 1986; Ker\& Resende, 1990; Bognola, 1996). É comum nos LB, perfis com horizonte B bicrômico, ou seja, B amarelado com matizes que variam de $5 \mathrm{YR}$ a $10 \mathrm{YR}$, avermelhando-se em profundidade, atingindo matizes mais vermelhas que 4YR na base deste mesmo horizonte (Carvalho 1982) (Quadro 6).

Algumas colocações têm sido feitas para explicar a bicromia de perfis como os LB e outros Latossolos no Brasil, uma vez que esta tendência de avermelhamento em profundidade é de ocorrência bastante generalizada na paisagem brasileira (Corrêa \& Resende, 1991) e mesmo a nível mundial (Schwertmann, 1971). Para casos dessa natureza, Schwertmann (1971) postula uma possível formação de hematita, responsável pela coloração avermelhada dos solos, favorecida por condições climáticas pretéritas mais quentes e secas. A instalação posterior de climas mais frios e úmidos, propiciaria um maior acúmulo de matéria orgânica, cujos componentes migrariam no solo dissolvendo a hematita por redução e/ou complexação do ferro e, por recristalização posterior, originaria a goethita, responsável pela coloração amarela.

Almeida (1979), por sua vez, postula que teores de

(6) Teste empregado e citado pelo saudoso Dr. Marcelo Nunes Camargo (EMBRAPA-SNLCS) em viagem de correlação de solos no Rio Grande do Sul e Santa Catarina. 
Quadro 6: Características químicas e físicas de alguns Latossolos Brunos do Brasil.

Table 6: Chemical and physical characteristics of some Brown Latosols in Brazil.

\begin{tabular}{|c|c|c|c|c|c|c|c|c|c|c|}
\hline & Prof & & $\mathrm{SiO}_{2}$ & $\mathrm{Al}_{2} \mathrm{O}_{3}$ & $\mathrm{Fe}_{2} \mathrm{O}_{3}$ & $\mathrm{TiO}_{2}$ & \multirow[b]{2}{*}{$\mathrm{Ki}$} & V & $\mathrm{m}$ & \multirow{2}{*}{$\begin{array}{l}\mathrm{Al}^{+++} \\
\mathrm{cmol}_{\mathrm{C}} / \mathrm{kg}\end{array}$} \\
\hline Horiz. & $\mathrm{cm}$ & Cor & \multicolumn{4}{|c|}{ 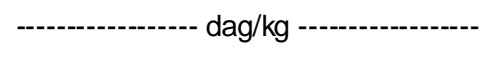 } & & \multicolumn{2}{|c|}{------- \% ------ } & \\
\hline \multicolumn{11}{|c|}{ Vacaria - RS (1) } \\
\hline Ap & $0-11$ & 10YR 3/4 & 22,4 & 19,1 & 17,8 & 3,49 & & 16 & 60 & 4,2 \\
\hline BA & $37-54$ & 7,5 YR $4 / 4$ & 25,2 & 22,6 & 18,5 & 3,85 & & 5 & 87 & 4,8 \\
\hline Bw2 & $90-135$ & $7,5 Y R \quad 4 / 5$ & 24,4 & 21,5 & 21,4 & 3,11 & 1,93 & 7 & 70 & 5,1 \\
\hline \multicolumn{11}{|c|}{ Anchieta - SC (2) } \\
\hline Ap & $0-23$ & $6 Y R$ 3/2,5 & 23,5 & 17,5 & 18,8 & 3,84 & & 35 & 9 & 0,7 \\
\hline BA & $47-72$ & $5 Y R 3 / 4$ & 25,1 & 20,4 & 18,5 & 3,24 & & 12 & 68 & 2,7 \\
\hline Bw2 & $105-220$ & 3,5YR 4/5,5 & 26,7 & 19,8 & 19,8 & 3,59 & 2,19 & 5 & 77 & 0,7 \\
\hline \multicolumn{11}{|c|}{ Guarapuava - PR (3) } \\
\hline Ap & $0-30$ & $7,5 Y R 3 / 4$ & 22,3 & 20,6 & 18,9 & 4,33 & & 5 & 80 & 5,3 \\
\hline BA & $80-110$ & 4YR 3,5/6 & 22,8 & 22,8 & 20,9 & 4,57 & & 5 & 84 & 3,2 \\
\hline Bw2 & $150-195$ & 1YR 3/6 & 24,2 & 23,8 & 21,4 & 4,43 & 1,73 & 2 & 85 & 0,7 \\
\hline \multicolumn{11}{|c|}{ Poços de Caldas - MG (4) } \\
\hline Ap & $0-25$ & 10YR 3/2 & 23,2 & 31,4 & 6,9 & 0,76 & & 29 & 28 & 1,5 \\
\hline $\mathrm{BA}$ & $40-58$ & $7,5 Y R$ S/6 & 22,4 & 30,8 & 8,2 & 0,91 & & 12 & 36 & 0,4 \\
\hline Bw2 & $110-153$ & $2,5 Y R 3 / 5$ & 22,5 & 31,9 & 9,7 & 1,02 & 1,20 & 9 & 0 & 0,0 \\
\hline
\end{tabular}

$\mathrm{Fe}^{3+}$ no sistema, mais que qualquer outro fator, favorecem a formação da hematita, mesmo sob condições de drenagem restrita, como, por exemplo, na gênese da plintita. Isso quer dizer que embora as condições pretéritas possam ter acelerado o processo de formação da hematita, ela não é, necessariamente, o fator de maior importância.

Ainda uma possível explicação para as colorações mais amareladas na parte superior do horizonte $\mathrm{B}$ dos LB e mesmo outros solos, seja a presença de elevados teores de matéria orgânica que, pela complexação do ferro liberado pelo intemperismo, inibiria a formação da ferrihidrita, o necessário percursor da hematita (Schwertmann \& Taylor, 1977). Nessas condições, a formação da goethita é favorecida.

A nível de campo, deslocando-se de regiões de altitudes, frias e úmidas, do sul do Brasil para aquelas mais quentes e baixas, constata-se uma gradação de solos de colorações brunadas ( $\mathrm{LB}, \mathrm{CB}$ e TB) até arroxeadas (LR) que confirmam o efeito da ação bioclimática , anteriormente referida, na gênese da goethita e hematita e, consequentemente, na coloração dos solos (Figura 6).

Embora morfologicamente parecidos, particularmente no que se refere à cor, desenvolvimento de estrutura e fendilhamento, os LB do sul do país apresentam diferenças químicas (Quadro 6) e mineralógicas marcantes em relação aos de Poços de Caldas -MG. Nos primeiros, os teores de $\mathrm{Fe}_{2} \mathrm{O}_{3}, \mathrm{TiO}_{2}$ e o Ki são maiores. Além disso, embora a mineralogia, da fração argila de todos eles seja parecida, sendo a caulinita o argilomineral predominante, os LB do sul apresentam quantidades maiores de vermiculita com hidroxi entre-camadas que os de Poços de Caldas e estes muito mais gibbsita que aqueles (Potter \& Kämpf 1981; Rodrigues, 1984; Ker \& Resende, 1990; Bognolla, 1996).

$\mathrm{O}$ fendilhamento relativamente intenso manifestado nestes solos é de difícil explicação. Entretanto, especulase uma possível contribuição da vermiculita com hidroxi entre-camadas ou mesmo caulinitas de pequeno tamanho (Ker \& Resende, 1990) e, talvez, haloisita (Palmiere, 1986) com maior capacidade de retenção de água, que ao desidratarem permitiriam a manifestação desta feição.

\section{Latossolo Variação Una}

Por ocasião do início dos trabalhos de levantamentos de solos no país, a tendência geral era reconhecer solos latossólicos de coloração amarelada 


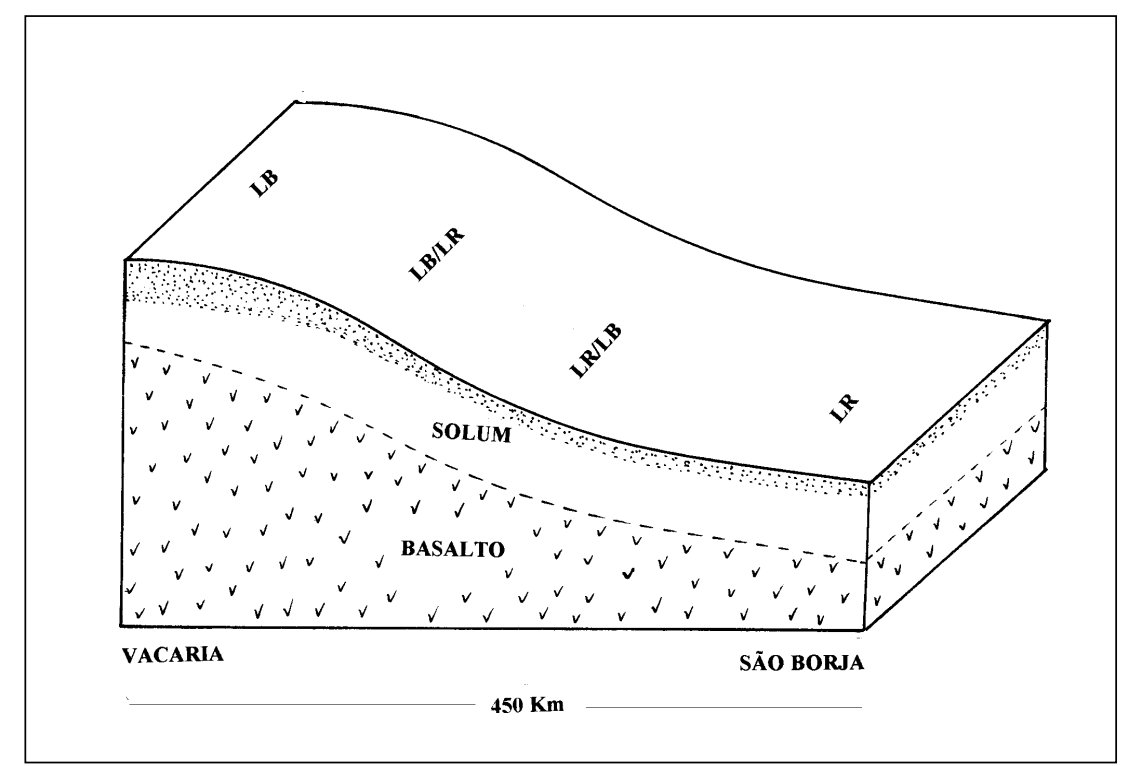

Figura 6 - Corte esquemático de uma climossequência de solos no Rio Grande do Sul, mostrando gradação de solos amarelados para avermelhados.

Fonte: Adaptado de BRASIL, 1972; KER et al., 1986; PALMIERI, 1986.

Figure 6: Climosequence of soil developed from Basalt with increasing red colours to the bottom.

como Latossolos Vermelho-Amarelos, independente dos teores de $\mathrm{Fe}_{2} \mathrm{O}_{3}$ provenientes do ataque sulfúrico. Já no início da década de sessenta, solo com a coloração anteriormente referida, porém com teores de ferro comparáveis aos de Latossolos Roxos, até então reconhecidos, foi identificado no sul da Bahia, no município de Una, e referendado preliminarmente como unidade Una (Bennema \& Camargo, 1964).

No segundo esboço de classificação de solos brasileiros Bennema \& Camargo (1964) propuseram a classe 5.2.3. dos Latossolos com alto teor de $\mathrm{Fe}_{2} \mathrm{O}_{3}(>$ $18 \%$ ) porém com cores mais amareladas que $2,5 \mathrm{YR}$, para englobar solos como os da "unidade Una" e alguns Latossolos Concrecionários de coloração amarelada identificados por Feuer (1956) na região de Brasília.

Com a publicação do Levantamento de Reconhecimento de Solos da Margem Direita do Rio São Francisco - Estado da Bahia (EMBRAPA-SNLCS, 1977), finalmente a classe "Latossolo Variação Una" apareceu como unidade taxonômica estabelecida. De forma resumida, foi assim definida: compreende solos minerais não hidromórficos, muito profundos, bem a acentuadamente drenados, distróficos de textura argilosa e muito argilosa com horizonte B de cores bruno-amarelada, bruno-forte e vermelho-amarelada, com teores médios a altos de $\mathrm{Fe}_{2} \mathrm{O}_{3}$ decorrentes da influência do material de origem: granulitos básicos e intermediários, biotita-diorito, biotita-gnaisse e diabásio.

Desde o seu reconhecimento, vários trabalhos foram desenvolvidos em materiais de Latossolos Variação Una de diferentes regiões do país e sob variados materiais de origem (Pessoa, 1979; Carmo et al., 1984; Curi \& Franzimeier, 1984; Oliveira et al., 1991). Alguns destes trabalhos, bem como aqueles oriundos de levantamentos pedológicos (EMBRAPA - SNLCS, 1977; Oliveira et al., 1983) permitiram o estabelecimento da seguinte definição de Latossolo variação Una (Camargo et al., 1987; EMBRAPASNLCS, 1988), até hoje em vigor: solos minerais não hidromórficos, com horizonte B latossólico com coloração mais amarelada que o matiz 3,5YR, com médios a altos teores de $\mathrm{Fe}_{2} \mathrm{O}_{3}(>11 \%)$, virtualmente sem atração magnética e índice Ki entre 0,2 e 2,0.

Apesar de normalmente álicos e distróficos, com horizonte A variando do moderado ao húmico, alguns perfis de Latossolos Variação Una eutróficos têm sido constatados no Brasil (Quadro 7).

Observa-se (Quadro 7) que os Latossolos Variação Una são também muito variáveis quanto à mineralogia, a inferir-se pelo Ki. Assim, são constatados desde solos muito gibbsíticos até aqueles mais cauliníticos, porém quase que exclusivamente goethíticos.

Finalmente, é importante destacar que os chamados "Latossolos Variação Una" constituem classe já com critérios de classificação estabelecidos, o que significa dizer que perde o sentido o termo "variação", mesmo porque o termo como empregado não é correto já que não é variação do conceito de Latossolo e sim de Latossolo Vermelho-Amarelo.

\section{Latossolo Húmico}

Esta classe engloba solos com B latossólico de horizonte A espesso, normalmente maior que $60 \mathrm{~cm}$, de coloração escura, refletindo o expressivo conteúdo de carbono orgânico. 
Quadro 7: Características químicas de alguns Latossolos Variação Una do Brasil.

Table 7: Chemical characteristic of some Una Variation Latosols in Brazil.

\begin{tabular}{|c|c|c|c|c|c|c|c|c|c|c|c|c|c|}
\hline \multirow[b]{3}{*}{ Localização } & \multicolumn{12}{|c|}{ Características Químicas } & \multirow[b]{3}{*}{ Ki } \\
\hline & \multicolumn{2}{|c|}{ pH } & $\mathrm{Ca}$ & Mg & Al & $\mathbf{H}$ & $\mathbf{S}$ & $\mathbf{T}$ & $\mathrm{SiO}_{2}$ & $\mathrm{Al}_{2} \mathrm{O}$ & $\mathrm{Fe}_{2} \mathrm{O}$ & $\mathrm{Ti}_{2} \mathrm{O}$ & \\
\hline & \multirow{2}{*}{$\frac{\mathrm{H}_{\mathbf{2}} \mathbf{O}}{5,1}$} & \multirow{2}{*}{$\begin{array}{c}\mathbf{K C l} \\
4,8\end{array}$} & \multicolumn{6}{|c|}{ - cmol/kg - - } & \multicolumn{4}{|c|}{ - } & \\
\hline Una-BA (1) & & & 0,8 & 0,2 & 0,3 & 8,3 & 1,10 & 3,7 & 18,6 & 22,7 & 21,0 & 2,14 & 1,39 \\
\hline Gandu-BA (1) & 4,9 & 4,8 & 0,5 & 0,3 & 3,7 & 0,90 & 4,9 & 23,9 & 27,9 & 25,1 & 1,66 & 1,45 & \\
\hline Manhuaçu-MG (2) & 4,2 & 5,0 & 0,3 & 0,0 & & 3,10 & 3,5 & 20,3 & 29,4 & 11,8 & 1,70 & 1,17 & \\
\hline Viçosa-MG (3) & 3,0 & 4,5 & 0,1 & 0,3 & 4,5 & 0,12 & 4,9 & 20,8 & 22,4 & 13,2 & 2,56 & 1,58 & \\
\hline Brasília-DF (4) & 5,5 & 6,7 & 0,1 & 1,1 & 0,0 & 0,6 & 1,20 & 1,8 & 9,0 & 30,6 & 17,8 & 1,26 & 0,50 \\
\hline Rio Paranaíba-MG (5) & 6,0 & 6,1 & 0,1 & 0,1 & 1,1 & 0,13 & 1,2 & 5,4 & 29,1 & 15,6 & 0,82 & 0,32 & \\
\hline Guaíra-SP (6) & 6,5 & 6,5 & 4,7 & 1,2 & 0,0 & 2,2 & 6,00 & 8,3 & - & - & - & - & - \\
\hline
\end{tabular}

(1) EMBRAPA - SNLCS, 1977; (2) OLIVEIRA et al., 1983; (3) KER \& SCHAEFER, 1995; (4) CARVALHO FILHO et al., 1993; (5) CARMO, 1977; (6) OLIVEIRA et al., 1991.

Tem sido constatado nas áreas de domínio dos Latossolos Ferrífero, Roxo, Vermelho-Escuro, Vermelho-Amarelo, Bruno e Variação Una, normalmente em regiões de altitude. Em termos de áreas mais contínuas e mapeáveis, ocorre de forma mais expressiva em regiões de clima ameno na divisa dos estados de Minas Gerais, Espírito Santo e Rio de Janeiro e Paraná com São Paulo e Santa Catarina (Figura 7).

Os Latossolos Húmicos são, em geral, álicos ou distróficos. A distrofia do sistema bem como as temperaturas amenas, inibem a atividade microbiana, favorecendo o acúmulo de matéria orgânica (RIBEIRO et al., 1972). Em razão disso, particularmente em áreas que permitem maior acúmulo de matéria orgânica, não é incomum encontrar Latossolos Húmico com horizonte A de mais de 1 metro de espessura.

\section{Latossolo Pálido}

Trata-se de classe de solo não reconhecida oficialmente no Brasil mas já referendada em viagem de correlação (Carvalho Filho et al., 1993) e trabalho de levantamento (áreas depressionais na Chapada das Covas, município de Silvânia - GO).

$\mathrm{Na}$ excursão de pedologia do XXIV Congresso Brasileiro de Ciência de Solo, o perfil 5, da área experimental da UnB, na cabeceira do Córrego Taquara

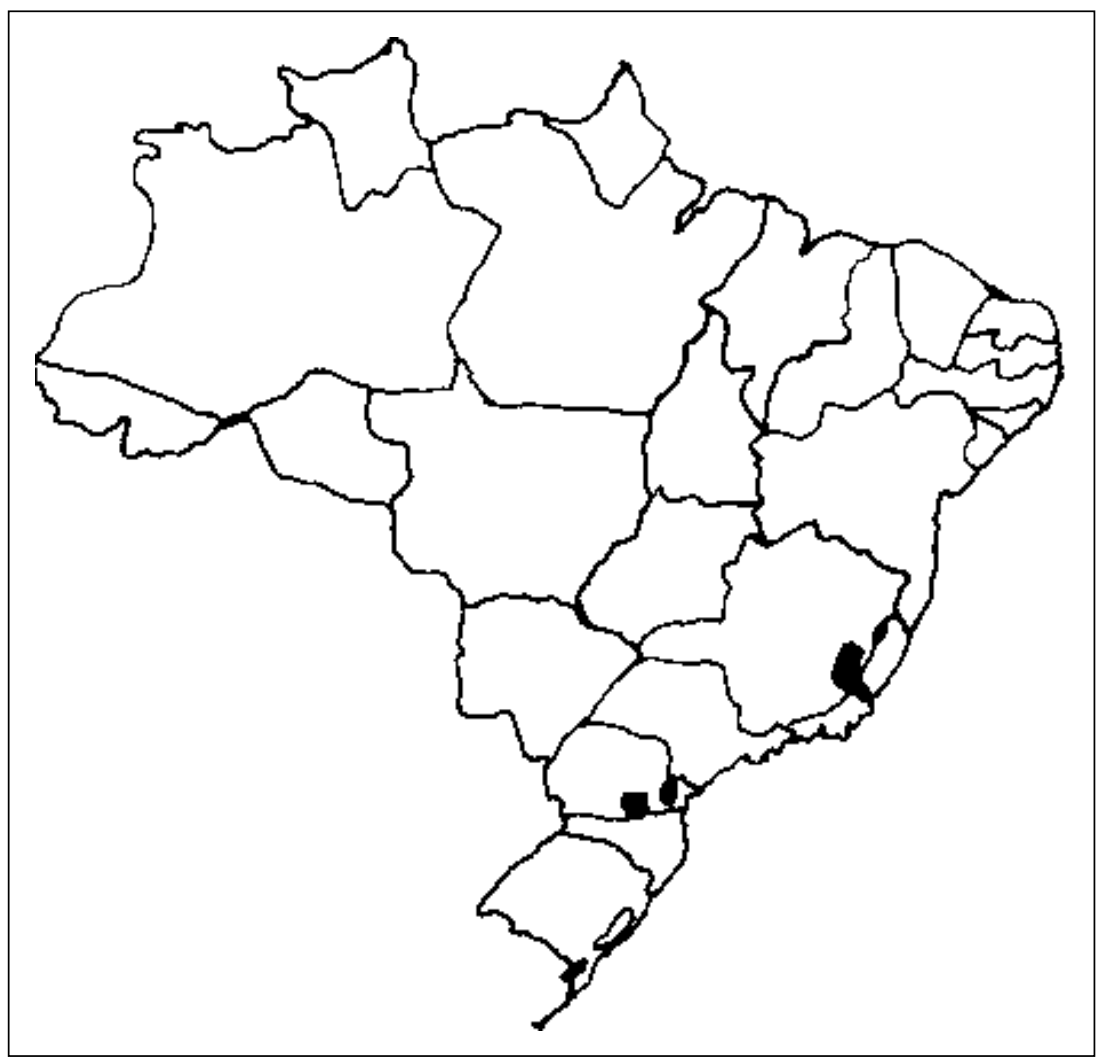

Figura 7: Representação esquemática da distribuição de Latossolos Húmicos no Brasil. Fonte: Mapa de Solos do Brasil (EMBRAPA - SNLCS, 1981).

Figure 7: Distribution of Humic Latosols in Brazil. Source: General soil map of Brazil, (EMBRAPA - SNLCS, 1981) 
- DF, foi tido como uma variação pálida do Latossolo Vermelho-Amarelo. O solo é caulinítico, muito argiloso, com baixos teores de $\mathrm{Fe}_{2} \mathrm{O}_{3}(<2,5 \%)$ e coloração brunoamarelada-clara (10YR 6/6) e amarelo-brunada (10YR 6/7) nos horizontes Bw1 e Bw2, respectivamente, ambos úmidos.

Baseando-se em algumas constatações de campo, esta classe, caso venha a ser reconhecida oficialmente no sistema de classificação que ora se desenvolve no país, deverá englobar solos de coloração amarelo-pálida ou mesmo acinzentada com valor alto e croma baixo, com baixos teores de $\mathrm{Fe}_{2} \mathrm{O}_{3}$ provenientes do ataque sulfúrico, ausência virtual de atração magnética, sem coesão expressiva na transição do horizonte A com B latossólico, como verificada nos Latossolos Amarelos de textura argilosa dos tabuleiros costeiros. Em várias situações deverão contemplar solos intermediários para Plintossolos e Gleissolos.

\section{RELAÇÕES GERAIS ENTRE OS LATOSSOLOS E SUPERFÍCIES DE APLAINAMENTO NO BRASIL}

Os Latossolos encontram-se amplamente distribuídos pelo Brasil (Figura 8). Como unidade dominante, ocupa cerca de um terço da superfície do território nacional, ocorrendo praticamente em todas regiões do país sob diferentes condições climáticas, relevo e material de origem.

Os Latossolos ocupam cerca de $41 \%$ da área da
Amazônia Legal brasileira (Rodrigues, 1996), 46\% da área dos Cerrados e $21 \%$ do Domínio Semi-árido (Jacomine, 1996), neste último caso sendo considerado como solos-testemunho de condições climáticas pretéritas mais úmidas. Expressiva ainda é sua ocorrência no domínio dos Mares de Morros e Planalto das Araucárias e de pouca expressividade na Campanha Gaúcha (Almeida, 1996) e Pantanal Mato Grossense.

Vários foram os estudos desenvolvidos em diferentes regiões do Brasil, correlacionando, ainda que de forma generalizada, a ocorrência dos Latossolos com superfícies de aplainamento, mesmo antes da publicação das superfícies reconhecidas por KING (1956) para o Brasil Oriental, algumas delas depois estendidas para o resto do território brasileiro, conforme Braun, 1982 citado por LEPSCH \& BUOL, 1986 (Figura 9).

Praticamente todos os estudos desenvolvidos objetivando estabelecer correlações entre a ocorrência dos Latossolos com superfícies geomórficas, destacam que esta classe de solos, ocupa preferencialmente as partes mais estáveis da paisagem, normalmente correlacionadas com a Superfície Sul Americana (Terciário Inferior) de KING (1956).

Exemplo clássico de remanescentes de superfície do ciclo Sul Americano, referem-se às amplas "chapadas" de relevo plano e suavemente ondulado do Planalto Central, onde normalmente encontram-se os solos mais intemperizados (oxídicos) do Brasil. Isso reflete o maior tempo de exposição ao intemperismo e lixiviação.

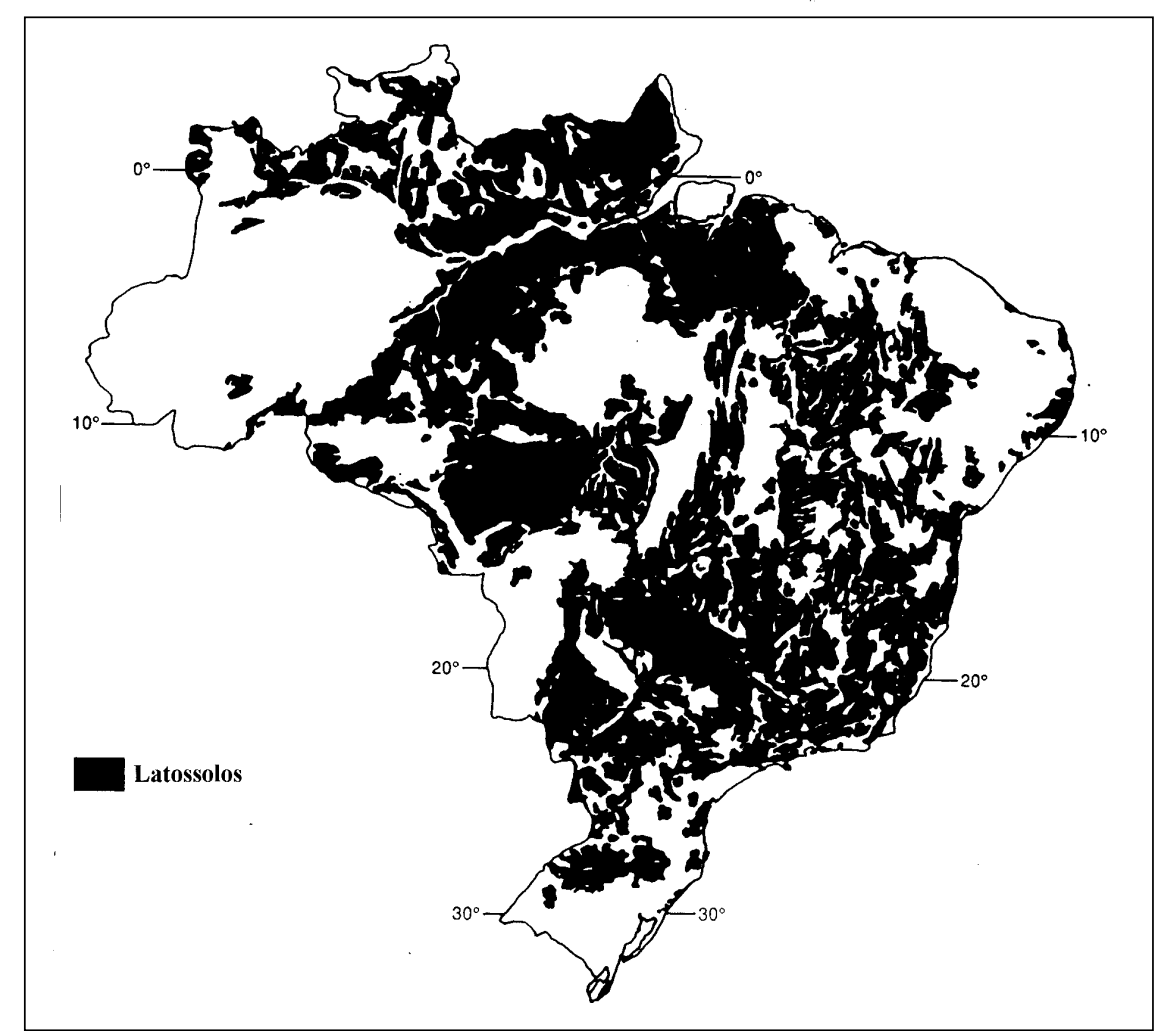

Figura 8: Distribuição das áreas de ocorrência de Latossolos no Brasil. Fonte: CAMARGO et al., 1986.

Figure 8: Distribution of all Latosols types in Brazil. 


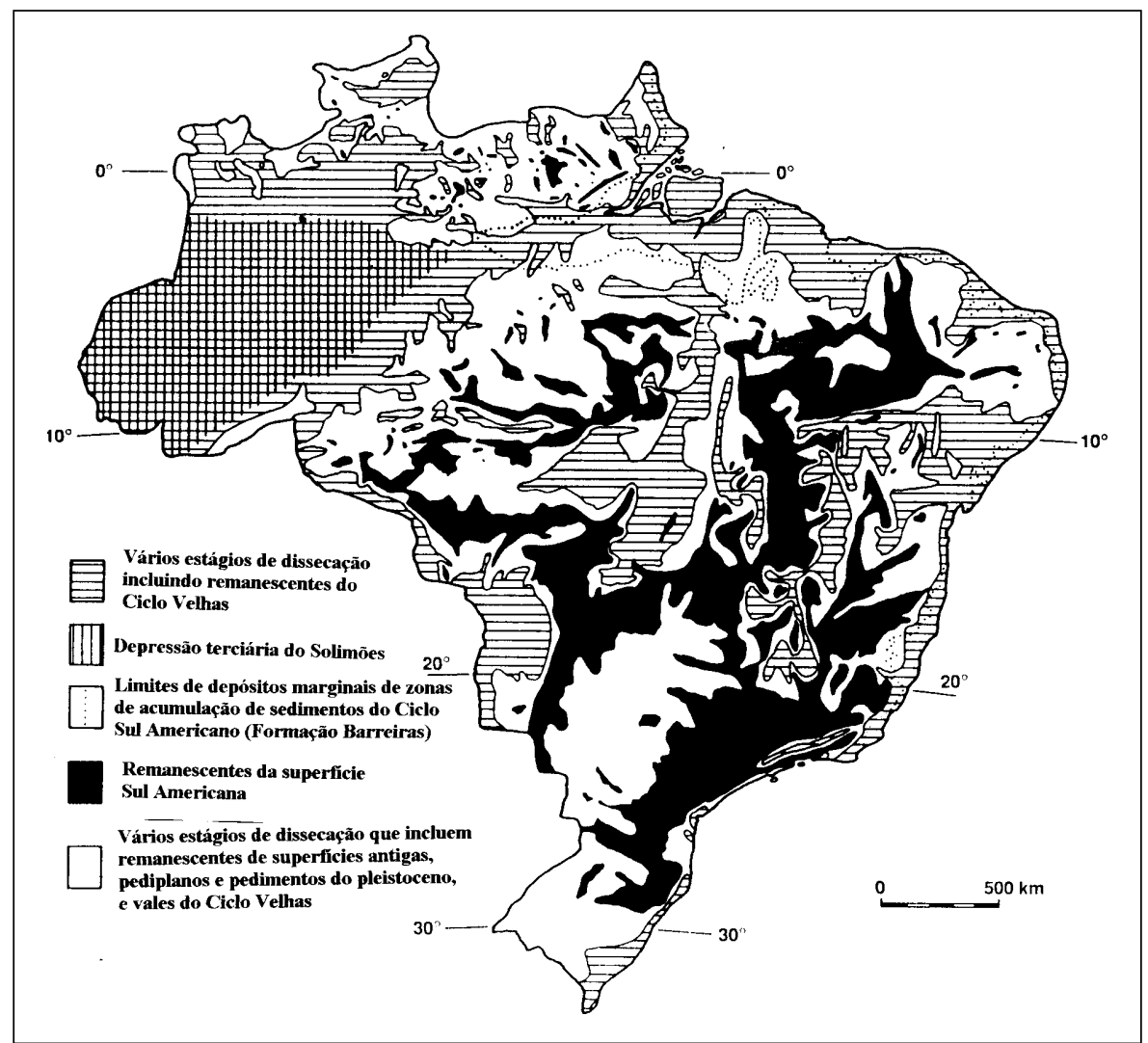

Figura 9: Distribuição generalizada de remanescentes de superfície referente à diferentes ciclos geomórficos descritos no Brasil. Fonte: Braun, 1982 citado por LEPSCH \& BUOL (1986).

Figure 9: General distribution of planation renmants of cyclic surfaces in Brazil, quoted by Lepsch \& Buol (1986).

Em áreas menos estáveis, correspondentes à superfície de aplainamento Velhas (Terciário Superior) do KING (1956), também verifica-se Latossolos; neste caso, são normalmente menos intemperizados e de mineralogia mais caulinítica. Em tais áreas é também muito comum a ocorrência de solos podzólicos associados.

Certamente, que tais afirmativas são de caráter generalizado e exemplos de solos muito intemperizados em condições de relevo movimentado são comuns na paisagem brasileira. Nestes casos, normalmente prevêse a deposição de material pré-intemperizado, que ganha estabilidade na nova posição de depósito (OLLIER, 1959; LEPSCH \& BUOL, 1987; CORRÊA, 1984). Assim, CORRÊA (1984) destaca a ocorrência de Latossolos Vermelho-Amarelos mais espessos, no sopé, em relação aos topos das elevações de segmentos da paisagem do sudeste mineiro.

Sumarizando, uma confrontação das figuras 9 e 10 , permite uma visualização geral da grande concordância entre as áreas de domínio dos Latossolos do Brasil e aquelas do domínio dos ciclos Sul Americano e Velhas de KING (1956).

\section{MINERALOGIA}

Os Latossolos são considerados poligenéticos. Experimentaram diferentes situações climáticas ao longo de sua formação. Isso tende a homogeneizar características químicas, morfológicas e mineralógicas. Assim, são considerados solos de mineralogia relativamente simples. Na sua fração grosseira (silte + areia) prevalece quartzo, com menores quantidades de muscovita e alguns feldspatos potássicos quando derivados de rochas ácidas. Magnetita e ilmenita com pequena proporção de quartzo prevalecem quando desenvolvem-se a partir de rochas básicas, com destaque para o basalto, no caso do Brasil. A magnetita pode ser importante fonte de elementos traços.

Na fração argila são variadas as quantidades de caulinita, gibbsita, goethita e hematita, à depender do tipo de material de origem, da intensidade do intemperismo e drenagem do sistema, entre outros fatores. Menores proporções de vermiculita com hidroxi entre camadas, ilita, anatásio, rutilo, maghemita e mesmo haloisita, também são constatados com frequência em determinados Latossolos (baseado em vários autores estudando Latossolos). Assim, o conceito central dos Latossolos, prevê o domínio de caulinita e óxidos de ferro e alumínio, com menores proporções de outros componentes na fração argila. 


\section{Gibbsita}

Durante o intemperismo de minerais primários e mesmo silicatos secundários, verifica-se a liberação de ferro, alumínio, sílica e íons diversos como $\mathrm{Ca}, \mathrm{Mg}$, $\mathrm{Na}, \mathrm{K}$, etc. Estes últimos, pela maior solubilidade tendem a ser lixiviados do sistema. A sílica, menos solúvel que eles, porém mais que o ferro e alumínio também tende a sair a depender da drenagem do meio. O pH de máxima estabilidade da gibbsita é 5,2 (Lindsay, 1979). Assim, todo alumínio liberado pelo intemperismo, precipita como gibbsita, desde que o potencial de sílica do meio seja baixo.

Embora a gibbsita seja considerada um mineral de ocorrência comum em diferentes classes de solos sob condições climáticas diversas, quantidades mais expressivas deste mineral tendem a ser encontradas nos Latossolos, onde a intensidade de intemperismo e lixiviação são maiores.

Dois mecanismos básicos têm sido propostos para explicar a origem da gibbsita em solos: 1) processo rápido de intemperismo nos estágios iniciais da alteração de aluminossilicatos, sobretudo feldspatos, onde a gibbsita pode ser um dos primeiros produtos de neoformação: 2) intemperismo intenso e de longa duração, envolvendo, inclusive a decomposição (dessilicificação) da caulinita. Em qualquer um dos casos, entretanto, condições de drenagem desimpedida, baixas atividades de sílica e bases em solução são requeridas (Harrinson, 1933; Gomes, 1976; Macías Vasquez, 1981; Aantonello, 1982; Rodrigues, 1984; Silva, 1985).

Normalmente a gibbsita pode originar-se a partir de uma gama considerável de materiais de origem, embora quantidades maiores deste mineral têm sido constatadas em rochas mais ricas em ferro (Moniz, 1967; Resende, 1976). Esta tendência, de acordo com Resende (1976), parece relacionar-se com um ou ambos dos seguintes fatos: 1) as rochas ricas em ferro são originalmente pobres em sílica, favorecendo a formação de gibbsita em detrimento da caulinita; 2) óxidos de ferro livre absorveriam a sílica não permitindo ou reduzindo sua capacidade de combinar-se com o alumínio para formar caulinita.

Onde a lixiviação não é tão intensa o alumínio liberado pode penetrar nas entre camadas de argilo minerais, formando, em geral, as vermiculitas com hidroxi entre-camadas, processo este determinado efeito anti-gibbsítico por Jackson (1964). Os Latossolos Brunos do Sul do Brasil parecem obedecer a este modelo de Jackson (Ker \& Resende, 1990).

\section{Óxidos de Ferro}

Os óxidos de ferro, termo genérico aqui empregado incluindo óxidos, hidróxidos e oxi-hidróxidos, encontram-se entre os principais componentes da fração argila dos Latossolos. Normalmente, ocorrem dispersos na massa do solo sob a forma de partículas finamente divididas, com grau de cristalinidade variado, capeando minerais de argila, ou mesmo sob a forma de complexos orgânicos (Oades, 1963; Schwertmann, 1985; Kämpf, 1988).

Goethita $(\mathrm{FeOOH})$, responsável pelas cores (matizes) amarelas ou brunadas dos solos (2,5Y/7,5YR) e hematita $\left(\mathrm{Fe}_{2} \mathrm{O}_{3}\right)$, impingindo cores vermelhas $(5 \mathrm{R} /$ 5YR), são as principais formas de ferro presentes na fração argila dos solos mais intemperizados e de melhor drenagem (Schwetmann \& Lentze, 1966; Segalen, 1969; Resende, 1976; Bighman, 1977; Schwertmann \& Taylor, 1977; Schwertmann, 1985; Kämpf, 1988; Schwertmann 1994).

A goethita, tida como a forma mais estável, é encontrada sob diversas condições ambientais, tendendo a ser a forma dominante nos solos (Schwertmann, 1985). Ocorre, também, em solos bastante avermelhados (Latossolos Roxos e Vermelho-Escuros), em proporções variáveis porém, sempre mascarada pelo efeito pigmentante da hematita (Resende, 1976). Já esta última, menos estável, pode estar ausente em solos mais amarelados, independente dos teores de ferro que apresentem (Kämpf \& Schwertmann, 1983).

Estes óxidos são, em geral, pedogenéticos e originam-se de minerais primários contendo ferro em suas estruturas, normalmente em estado divalente. Após intemperização, o ferro liberado passa para solução, oxida-se $\left(\mathrm{Fe}^{+++}\right)$e precipita como ferrihidrita, se a taxa de liberação ultrapassar o produto de solubilidade deste óxido. Caso contrário, precipita-se como goethita. (Schwertmann \& Taylor, 1977; Kämpf, 1988).

Se as condições do meio foram favoráveis, isto é, baixa atividade de sílica em solução e baixos teores de matéria orgânica, resultando em menor complexação do ferro, a ferrihidrita, mineral de pior cristalinidade, origina a hematita, através de rearranjos internos e desidratação. Assim, este mineral é tido como o necessário precursor da hematita (Schwertmann \& Taylor, 1977). Estas condições são normalmente observadas quando a drenagem é livre e as temperaturas, regime de umidade e $\mathrm{pH}$ mais elevados, favorecendo as maiores taxas de intemperismo (liberação do ferro), maior mineralização da matéria orgânica e lixiviação de sílica (menor complexação do ferro). Por outro lado, se fatores do meio não favorecem estas condições, haverá dissolução da ferrihidrita e formação de goethita.

Deve-se destacar que, quando as condições do meio não forem favoráveis no que se refere à drenagem, a hematita também pode estar presente, concentrada em mosqueados ou sob a forma de plintita. Neste caso, postula-se que em períodos de melhor drenagem (abaixamento do lençol freático), verifica-se uma acumulação localizada de $\mathrm{Fe}^{+++}$que, mesmo com a alteração das condições do meio para situações de drenagem mais restrita, persistiria no sistema devido às alterações das condições de $\mathrm{pH}$.

Peculiaridade comum tanto de goethitas como de 
hematitas de solos e de outros ambientes naturais referese à substituição do ferro pelo alumínio em suas estruturas cristalinas. Em geral, a substituição na goethita é praticamente o dobro que a da hematita (Schulze, 1982). Valores máximos de substituição da ordem de 46 e 23 moles de Al\% têm sido constatados para goethitas e hematitas naturais, respectivamente. Neste contexto, as goethitas parecem mais estudadas e alguns resultados de substituição isomórfica do ferro pelo alumínio são apresentados no quadro 8.

O efeito da substituição do ferro por alumínio na estrutura cristalina destes minerais, pelo menos para óxidos sintéticos, refere-se à diminuição do tamanho da célula unitária, devido ao menor raio iônico do alumínio $(0,053 \mathrm{~nm})$, em relação ao do ferro $(0,065$ $\mathrm{nm}$ ), portanto, cerca de $20 \%$ menor (Norrish \& Taylor, tendência de maiores valores de substituição, provavelmente em razão da maior acidez e, consequentemente, maior atividade de alumínio em solução (Schwertmann, 1985). Assim, os Latossolos mais gibbsíticos tenderiam a apresentar óxidos de ferro mais aluminizados.

A afirmativa do parágrafo anterior deve ser vista com ressalvas, ou mais testada em solos. Rezende (1980), por exemplo, observou para solos latossólicos e podzólicos de Minas Gerais, relação inversa entre a substituição isomórfica na goethita e teores de gibbsita. Este autor destaca ainda variação na substituição ao longo do perfil.

O grau de substituição isomórfica na estrutura dos óxidos de ferro, por sua vez, parece correlacionar-se com a estabilidade destes óxidos no ambiente. Goethitas

Quadro 8: Valores de substituição isomórfica do ferro pelo alumínio na estrutura da goethita de solos e de outros materiais de várias partes do mundo.

Table 8: Isomorphic replacement of Al in goethite in soils and other materials from different parts of the word.

\begin{tabular}{ccccc}
\hline Solos & Localização & Amostras & $\begin{array}{c}\text { Subst. Al } \\
\text { (mol \%) }\end{array}$ & Referência \\
\hline $\begin{array}{c}\text { Materiais Ferruginosos } \\
\text { de Lagos }\end{array}$ & Finlândia & 16 & $<3$ & 1 \\
$\begin{array}{c}\text { Concreções em Solos } \\
\text { Hidromórficos }\end{array}$ & Europa Central & 10 & $<3$ & 1 \\
$\begin{array}{c}\text { Solos Hidromórficos } \\
\text { Latossolos e }\end{array}$ & África do Sul & 44 & $0-10$ & 2 \\
$\begin{array}{c}\text { Cambissolos } \\
\text { Latossolos, }\end{array}$ & Sul do Brasil & 47 & $11-25$ & 3 \\
$\begin{array}{c}\text { Cambissolos, Terra } \\
\text { Bruna e Roxa } \\
\text { Latossolos }\end{array}$ & Sul do Brasil & 10 & $13-22$ & 4 \\
Latossolos & Triângulo Mineiro & 6 & 30 & 5 \\
Batossolos & $\begin{array}{c}\text { Várias regiões do } \\
\text { Brasil }\end{array}$ & 12 & $24-36$ & 6 \\
Latossolos & Sul do Brasil & 14 & $7-33$ & 8 \\
\hline-
\end{tabular}

1 - SCHWERTMANN, 1985; 2 - FITZPATRICK \& SCHWERTMANN, 1982;

3 - SCHWERTMANN \& KÄMPF, 1985; 4 - PALMIERI, 1986; 5 - RESENDE, 1976;

6 - CURI, 1983; 7 - KER, 1995; 8 - MÖLLER, 1991

1961; Schulze, 1982; Schwertmann, 1985). Em consequência, estes óxidos de ferro aluminizados, apresentariam maior área específica e reatividade. Pelo menos em ambiente heterogêneo como o do solo, esta relação nem sempre tem sido observada (Gualberto et al., 1987; Möller, 1991; Ker, 1995).

A substituição isomórfica do ferro pelo alumínio, na estrutura da goethita e mesmo hematita tem sido correlacionada com algumas condições ambientais. Pelo quadro 8 observa-se menor tendência de substituição isomórfica na goethita em condições de hidromorfismo, possivelmente pela menor atividade do alumínio em solução nestas condições, ditada por valores mais elevados de $\mathrm{pH}$.

Em condições de melhor drenagem, particularmente no caso de Latossolos, observa-se (Quadro 8) uma mais aluminizadas tendem a ser menos susceptíveis à redução (Schwertmann, 1985). Macedo \& Bryant (1987) em estudos de solos do Planalto Central do Brasil, destacam como possível causa da maior dissolução da hematita, favorecida pela presença de compostos orgânicos, atividade biológica e lençol freático elevado, à sua menor substituição isomórfica em relação à goethita.

Um outro óxido de ferro bastante comum em Latossolos brasileiros, sobretudo aqueles avermelhados e desenvolvidos de rochas máficas e itabiríticas, é a maghemita (Rauen, 1980; Curi, 1983; Resende et al., 1986; Ker, 1995; Bognolla, 1996).

Sua origem parece estar ligada à oxidação total ou parcial da magnetita (Schwertmann \& Taylor, 1977); da titano magnetita herdada do próprio material de 
origem (Resende et al., 1986), ou ainda, pela transformação de outros óxidos de ferro pedogenéticos por aquecimento. Neste último caso, a prática da queima poderia levar à sua formação (Schwertmann, 1985). Isso não tem sido verificado na prática, pois se assim o fosse, nos cerrados brasileiros este mineral seria comum o que não é realidade. Assim, sua origem no solo parece mais relacionada à herança ou transformações a partir de rochas máficas e itabiríticas.

A exemplo da magnetita, sua principal característica reside na elevada atração magnética que, por sua vez, tem revelado boa correlação com o conteúdo de alguns elementos traços presentes nos solos, sobretudo cobre, zinco e níquel (Ker, 1995), particularmente em se tratando de solos desenvolvidos de rochas máficas.

\section{Caulinita}

A caulinita é um dos minerais mais abundantes na crosta terrestre. Origina-se a partir da alteração de um número considerável de minerais primários, destacandose os feldspatos e as micas, ou secundários (degradação de argilas 2:1), em condições ambientais diversas. De forma mais expressiva, porém não exclusivamente, condições de clima mais quente e úmido, drenagem livre porém sem que se verifique uma lixiviação excessiva de sílica do sistema, e meio ácido, favorecem sua gênese (Jackson \&Schwertmann, 1953; Keller, 1968; Calvert, 1981; Dixon, 1989). Todas estas condições são comuns nos trópicos e justificam a grande abundância deste mineral na fração argila dos solos tropicais, com destaque para os Latossolos.

Embora muitas vezes seja referida como um mineral simples, de forma e estrutura cristalina definidas, nos solos, tem-se na verdade, uma verdadeira família englobada sob a denominação caulinita, bastante variável no que se refere ao tamanho, empacotamento de camadas, imperfeições cristalográficas etc (Cases et al., 1982).

As caulinitas dos solos são normalmente de pior cristalinidade que aquelas de depósitos geológicos (Hhghes \& Brown, 1979; CAses et al., 1982; Herbillon, 1980). Várias tem sido as razões apontadas para isso, dentre elas (material de origem, cor, drenagem), a substituição do alumínio por ferro nas posições octaedrais causando desorganização estrutural da caulinita tem sido mais comentada e aceita. Assim, vários estudos têm apontado relação inversa entre o conteúdo de ferro e índices de cristalinidade de caulinitas (Plaçon \& Tchoubar, 1977; Mestdagh et al., 1980).

Em solos brasileiros, Moniz (1967) e Resende (1976) destacam a ocorrência de caulinitas mais desordenadas naqueles desenvolvidos de rochas máficas. Nestes casos além da possível contribuição do ferro como substituinte do alumínio nos octaedros de caulinita, postula-se também a participação deste elemento e mesmo titânio, acomodados em sua estrutura sem promover desorganização (Mestdagh et al., 1980), porém inibindo sua nucleação e, em consequência, e melhor expressão de sua cristalinidade.

Vários métodos empíricos vêm sendo empregados visando estabelecer índices de "cristalinidade" de caulinitas. A maioria deles baseia-se na difratometria de raios-X, onde são estabelecidas relações entre as intensidades de alguns picos e/ou a alteração da linha de base do difratômetro quando caulinitas de melhor e pior cristalinidade são avaliadas.

Dentre os vários índices propostos, o de Hughes \& Brown (1979) tem sido empregado para avaliação da cristalinidade de caulinita em solos. Tal índice baseiase na relação entre $h_{1}$ e $h_{2}$, onde $o h_{1}$ refere-se a intensidade do pico da caulinita entre 22 e $17^{\circ} 2 \theta$ ou 24 e $20^{\circ} 2 \theta$ para CuK e CoK, respectivamente, e $h_{2}$ a depressão verificada próximo a $44^{\circ}$ ou $37,6^{\circ} 2 \theta$ para as mesmas fontes de radiação (Figura 10).

Assim, Ker (1995) encontrou valores de índice de cristalinidade entre 8,0 e 15,0 para caulinitas da fração argila desferrificada de nove Latossolos brasileiros com diferentes teores de ferro (Quadro 9). Estes valores encontram-se em harmonia com aqueles encontrados por Hughes \& Brown (1979) para solos da Nigéria, e muito aquém daqueles obtidos para caulinita de boa cristalinidade como a Ka-Ba (Quadro 9) e outras de várias partes do mundo.

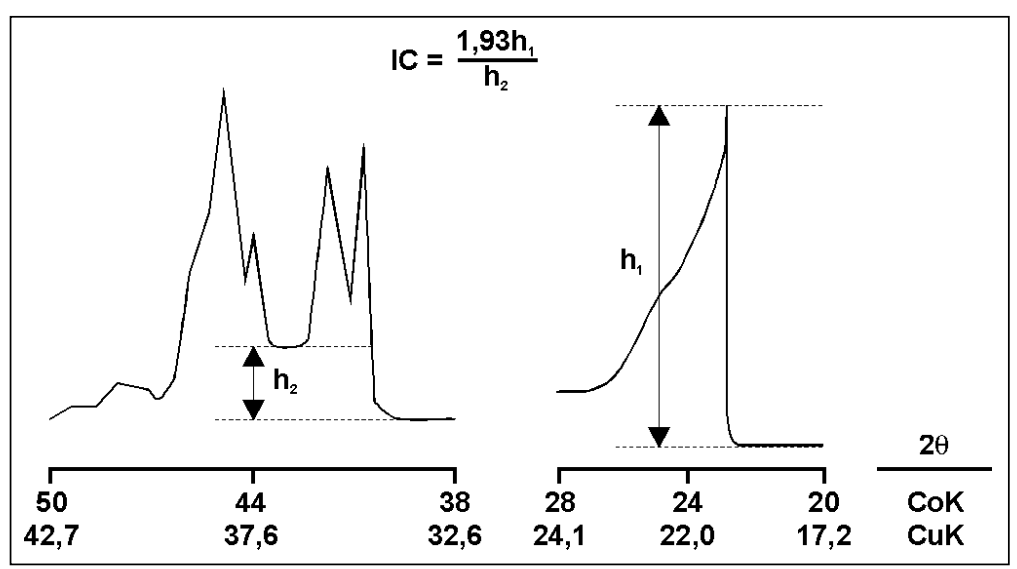

Figura 10: Picos de caulinita em duas regiões do difratograma de Raios-X utilizados no cálculo do índice de cristalinidade de HUGHES \& BROWN (1979).

Figure 10: Kaolinite peaks obtained by DRX anel used for calculation of crystalillinity radex proposed by Hughes \& Brown 1979). 
Embora a cristalinidade da caulinita não esteja diretamente relacionada com seu tamanho (Oberlin et al.; 1961 e Wiewora \& Brindley, 1969, citados por Herbillon, 1980), tem-se observado que caulinitas de solos normalmente apresentam áreas específicas maiores que aquelas de depósitos geológicos de melhor cristalinidade. Ker (1995) assumindo formas mais ou menos equidimencionais para caulinitas de solos, empregou a fórmula da área do cilindro para a determinação de suas superfícies específicas na fração argila de Latossolos brasileiros. Para tanto, arbitrou, baseando-se em informações de literatura, raio de 200 $\mathrm{nm}$ e altura igual ao diâmetro médio do cristalito perpendicular ao seu plano 001. Os valores encontrados (Quadro 10) revelam que as caulinitas de solos apresentam áreas superiores àquela obtida para uma caulinita bem cristalizada proveniente de depósitos geológicos da Georgia - USA.

\section{RELAÇÃO ENTRE PROPRIEDADES QUÍMICAS, FÍSICAS E MINERALÓGICAS DOS LATOSSOLOS E ASPECTOS AMBIENTAIS}

Os Latossolos são, em geral, muito permeáveis. Esta permeabilidade é função da textura e da própria mineralogia. Aqueles de textura média ou, mesmo, argilosa ou muito argilosa quando gibbsíticos, são os mais permeáveis (Ferreira, 1988). Isso favorece a lixiviação. Nessa classe de solo, a única exceção são os Latossolos Amarelos; são os menos permeáveis.

Por sua expressão e situação geográfica, condição de relevo, entre outros aspectos, os Latossolos constituem a classe de solo de maior utilização agrícola no país (inclui: cultivos diversos, reflorestamento e pastagens). Em consequência da intensa utilização agrícola, sendo comuns duas safras/ano agrícola nas áreas onde a precipitação pluviométrica é suficiente e bem distribuída, ou três quando sob irrigação, a erosão é inevitável e séria. Isso, apesar de que técnicas e o grau de conscientização do agricultor venham melhorando ultimamente.

Estes dois fatores: erosão e infiltração comprometem os mananciais de água, quer assoreando, quer poluindo com toda sorte de resíduos de produtos atinentes à atividade agrícola (corretivos, adubos e pesticidas em geral).

Se a lixiviação (infiltração) e a erosão exportam, a reatividade modifica. $\mathrm{O}$ papel do solo como ambiente de decomposição e reação passa a ser decisivo na qualidade do ambiente (Resende \& Ker, 1996). Neste contexto, a matéria orgânica e os óxidos do solo são de
Quadro 9: Valores de Índice de Cristalinidade (IC) de caulinitas do horizonte $B$ de Latossolos e depósito geológico de acordo com Hughes \& Brown (1979).

Table 9: Crystalinity index of kaolinites of B horizons of Latossols and geological deposits (after Hughes \& Brown, 1979).

\begin{tabular}{ccc}
\hline Material & Clas. & IC \\
Ka-Ba (1) & Ka-Bahia & 80,0 \\
K2 & LR & 9,0 \\
K16 & LE & 8,0 \\
K22 & LE & 8,0 \\
K21 & LU & 6,0 \\
K24 & LU & 15,0 \\
K7 & LV & 11,0 \\
K11 & LV & 15,0 \\
K20 & LA/LV & 14,0 \\
K4 & LR & 11,0 \\
\hline
\end{tabular}

(1) Caulinita proveniente da Bahia, cedida pela M. Millot, da Seção de Mineralogia da ORSTOM, Bondy - França

suma importância. A primeira pelo seu poder de complexação dos pesticidas. Os segundos, principalmente os de ferro e manganês, pela sua capacidade de reação com alguns elementos no solo, às vezes potencialmente prejudiciais à saúde $(\mathrm{Cd}, \mathrm{Cr}$, $\mathrm{Pb}$ etc). Este papel dos óxidos, maior que o efeito da concentração salina, também tem sido registrado em sedimentos aquáticos de estuários brasileiros (Lacerda et al., 1989).

Os Latossolos têm alto poder de adsorção de fósforo (Leal, 1971; Novais et al., 1991; Ker, 1995). A adsorção tende a aumentar com os teores de argila, de goethita e de gibbsita no solo. A adsorção de $\mathrm{P}$ é rápida e uma vez adsorvido sua dessorção se torna tão mais difícil quanto maiores os teores de goethita e gibbsita (Figura 11). Isso reduz muito os perigos de eutrofização de lagos uma preocupação constante dos ambientalistas.

\section{REFERÊNCIAS BIBLIOGRÁFICAS}

ALEVA, G.J.J. The CORLAT Handbook; draft version 1.2. Brussels, International Soil Reference and Information Center, 1992. 91p. (Corlat Technical Publication, 1).

ALMEIDA, J.R. Cronocromosequência de solos originários de rochas pelíticas do Grupo Bambuí. Viçosa, UFV, 1979. 150p. (Tese M.S.)

ALMEIDA, J.A. Solos dos pampas. In: ALVAREZ, V.H.V.; 
Quadro 10: Superfície específica e dimensão média dos cristalitos avaliadas nas reflexões 001 (DMC001) de caulinitas da fração argila de horizontes B de Latossolos do Brasil.

Table 10: Specific surface and cristalite dimension of kaolinites from clay fraction of B horizons of Latosols in Brazil.

\begin{tabular}{|c|c|c|c|}
\hline \multirow[t]{2}{*}{ Materiais } & \multirow{2}{*}{$\begin{array}{l}\text { Identificação/ } \\
\text { Classificação }\end{array}$} & \multicolumn{2}{|c|}{ Caulinita } \\
\hline & & DMC001 & Sup. Espec. \\
\hline & & $-\mathrm{nm}-$ & $\mathrm{m}^{2} / \mathrm{g}$ \\
\hline G1 (1) & Ka - Georgia & 107 & 15 \\
\hline G2 & Ka - Georgia & 38 & 38 \\
\hline $\mathrm{K} 1$ & LR & 24 & 34 \\
\hline $\mathrm{K} 2$ & LR & 18 & 50 \\
\hline K6 & LR & 34 & 30 \\
\hline $\mathrm{K} 17$ & LR & 58 & 21 \\
\hline K18 & LR/LE & 34 & 30 \\
\hline $\mathrm{K} 23$ & LR & 34 & 30 \\
\hline K26 & LR & 18 & 50 \\
\hline K27 & LR & 38 & 28 \\
\hline K16 & LE & 24 & 39 \\
\hline K22 & LE & 18 & 50 \\
\hline K9 & LU & 30 & 33 \\
\hline $\mathrm{K} 13$ & LU & 46 & 24 \\
\hline K15 & LU & 49 & 33 \\
\hline K21 & LU & 21 & 44 \\
\hline K24 & LU & 21 & 44 \\
\hline K28B1 & LU & 49 & 25 \\
\hline K28B2 & LU & 49 & 23 \\
\hline K3 & LV & 58 & 21 \\
\hline K7 & LV & 30 & 33 \\
\hline K8 & LV & 49 & 23 \\
\hline K11 & LV & 25 & 38 \\
\hline K20 & LA/LV & 34 & 30 \\
\hline K25 & LB & 17 & 52 \\
\hline $\mathrm{K} 14$ & LB/TB & 28 & 35 \\
\hline $\mathrm{K} 4$ & LP & 49 & 23 \\
\hline K5 & LP & 43 & 25 \\
\hline
\end{tabular}

(1) Caulinitas de depósitos geológicos, incluídas para comparação, cedidas pelo professor Liovando Marciano da Costa, do Departamento de Solos da Universidade Federal de Viçosa (G1 e G2, de melhor e pior cristalinidade, respectivamente).

FONTES, L.E.F.; FONTES, M.P.F. eds. Os solos nos grandes domínios morfoclimáticos do Brasil e o desenvolvimento sustentado. Viçosa, SBCS/UFV, 1996. p. 298-306.

ANJOS, L.H.C. Caracterização, gênese, classificação e aptidão agrícola de uma sequência de solos do terciário na região de Campos - RJ. Itaguaí, UFRRJ, 1985. 194p. (Tese M.S.)

ANTONELLO, L.L. Gênese de uma sequência de solos de rochas alcalinas do maciço alcalino do Itatiaia, RJ; mineralogia, geoquímica e micromorfologia. Rio de Janeiro, UFRJ, 1982. 262p. (Tese D.S.)

ANTONELLO, L.L.; MÖLLER, R.A.L.; MONIZ, A.C.; DURIEZ, M.A.M. Mineralogia de argilas desferrificadas de "horizonte B" em latossolos do Sudeste e Sul do Brasil.In: Reunião de classificação, correlação de solos e interpretação de aptidão agrícola, 3, Rio de Janeiro, 1988. Anais... Rio de Janeiro, EMBRAPA - SNLCS - SBCS, 1988. p.185-210.

BARRETO, W.O. Eletroquímica de solos tropicais de carga variável; capacidade da dupla camada elétrica. Itaguaí, UFRRJ, 1986. 273p. (Tese D.S.)

BENNEMA, J. \& CAMARGO, M.N. Segundo esboço parcial de classificação de solos brasileiros. Rio de Janeiro, Ministério da Agricultura, Divisão de Pedologia e Fertilidade do Solo, 1964. 17p. (mineogr.).

BENNEMA, J. \& CAMARGO, M.N. Some remarks on brazilian latosols in relation to the oxisols of soil taxonomy. In: Internation soil classification workshop, 2. Malaysia, 1978. Proceedings... 


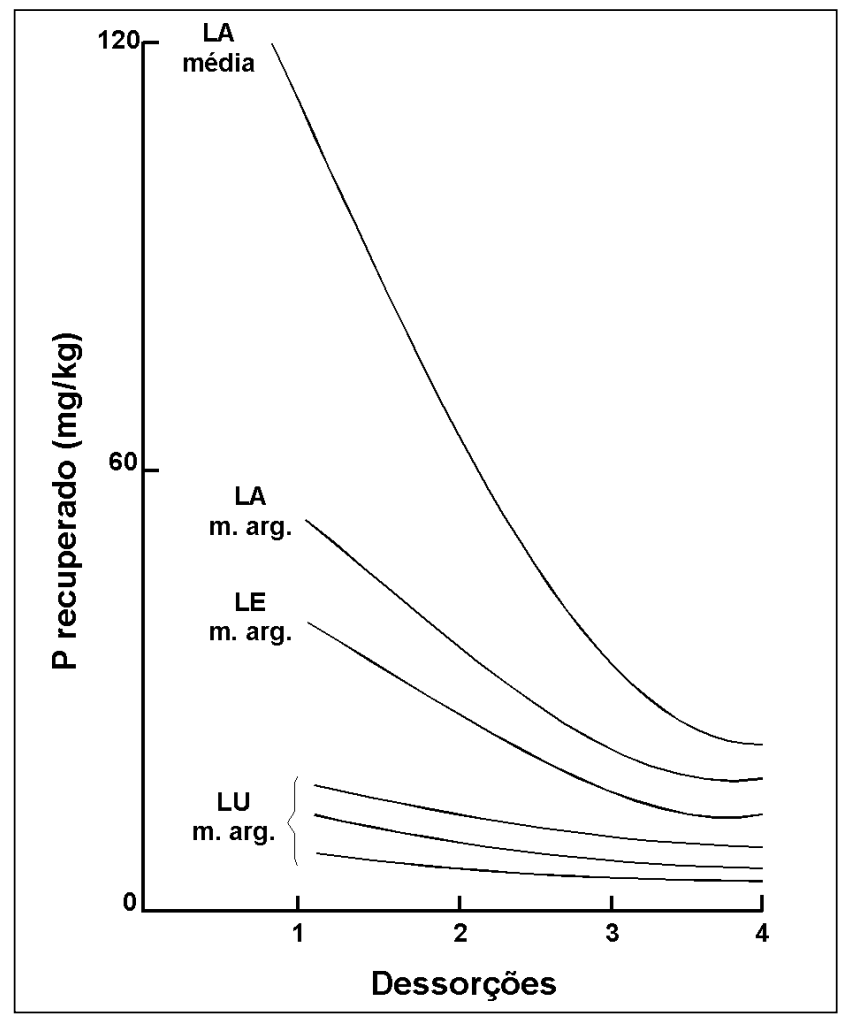

Figura 11: Fósforo recuperado em quatro tratamentos sucessivos com resina de troca aniônica de alguns Latossolos brasileiros ( $L=$ Latossolo; $A=$ Amarelo; $E=$ Vermelho-Escuro; $U=U n a ;$ média = textura média; $m$. arg. = textura muito argilosa). Fonte: KER, 1995.

Figure 11: Recovered $P$ after four sucessive treatments with amonic resin of Brazilian Latosols.

Bangkok, SSD - LDD, 1979. p. 233-235.

BIGHAM, J.M. Iron mineralogy of red-yellow hued ultisols and oxisols as determined by Mössbauer Spectroscopy X-ray diffractometry, and supplemental laboratory techniques. Raleigh, North Caroline State University, 1977. 165p. (Tese Ph.D.)

BOGNOLA, I.A. Caracterização química, física e mineralógica de solos intermediários entre Latossolos Brunos e Latossolos Roxos. Viçosa, MG, UFV, 1996. 205p. (Tese M.S.).

BRASIL. Ministério da Agricultura. Centro Nacional de Ensino e Pesquisas Agronômicas. Levantamento de reconhecimento dos solos do Estado do Rio de Janeiro e Distrito Federal. Rio de Janeiro, Serviço Nacional de Pesquisas Agronômicas, Comissão de Solos, 1958. 350p. (SNPA, Boletim 11).

BRASIL. Ministério da Agricultura. Centro Nacional de Ensino e Pesquisas Agronômicas. Comissão de Solos. Levantamento de reconhecimento de solos da região son influência do reservatório de Furnas. Rio de Janeiro, Serviço Nacional de Pesquisas Agronômicas, , 1962. 462p. (SNPA, Boletim 13).

BRASIL. Ministério da Agricultura. Centro Nacional de Ensino e Pesquisas Agronômicas. Levantamento de reconhecimento dos solos do Estado de São Paulo. Rio de Janeiro, Serviço Nacional de Pesquisas Agronômicas, Comissão de Solos, 1960. 634p. (SNPA, Boletim 12).

BRASIL. Ministério da Agricultura. Divisão de Pesquisa Pedológica, DNPEA. Levantamento de reconhecimento dos solos do Estado do Mato Grosso. Rio de Janeiro. 1971. 839p. (Boletim Técnico, 18).

BRASIL. Ministério da Agricultura. Divisão de Pesquisa Pedológica, DNPEA. Levantamento exploratório-reconhecimento de solos do Estado do Rio Grande do Norte. Recife, Convênio MA/ DNPES-SUDENE/DRN, MA/USAID/BRASIL. 1971. 530p. (Boletim Técnico, 21).

BRASIL. Ministério da Agricultura. Divisão de Pesquisa Pedológica, DNPEA. Levantamento exploratório-reconhecimento de solos do Estado do Ceará. Recife, Convênio MA/DNPES-SUDENE/ DRN, MA/CONTAP/USAID/ETA. 1973. 502p. (Boletim Técnico, 28).

CALVERT, C.S. Chemistry and mineralogy of iron substituted kaolinite in natural and synthetic systems. Texas, A \& M University, 1981. 224p. (Tese Ph.D.)

CAMARGO, M.N. Proposição preliminar de conceituação de latossolos ferríferos. In: EMPRESA BRASILEIRA DE PESQUISA AGROPECUÁRIA. Serviço nacional de Levantamento e Conservaçõ do Solo - EMBRAPA - SNLCS. Conceituação sumária de algumas classes de solos recémreconhecidas nos levantamentos e estudos de correlação do SNLCS. Rio de Janeiro, 1982. p. 29-31 (Circular Técnica 1)

CAMARGO, M.N.; KLAMT, E.; KAUFFMAN, J.H. Classificação de solos usada em levantamento pedológico no Brasil. Boletim Informativo da Sociedade Brasileira de Ciência de Solo, 12(1): 11-33, 1987.

CARMO, D.N. Caracterização, gênese e uso de latossolos sob cerrado no município de Rio Paranaíba. Lavras, MG, ESAL, 1977. 74p. (Tese M.S.)

CARMO, D.N.; CURI, N.; RESENDE, M. Caracterização e gênese de latossolos da região do Alto Paranaíba (MG). R. bras, Ci. Solo, 8::235-240, 1984.

CARVALHO, A.P. Conceituação de Latossolo Bruno. In: EMPRESA BRASILEIRA DE PESQUISA AGROPECUÁRIA. Serviço nacional de Levantamento e Conservaçõ do Solo - EMBRAPA - SNLCS. Conceituação sumária de algumas classes de solos recém-reconhecidas nos levantamentos e estudos de correlação do SNLCS. Rio de Janeiro, 1982. (Circular Técnica 1)

CARVALHO FILHO, A.; FRAGA, A.G.F.; MOTTA, P.E.; OLIVEIRA, V.A. Guia de escursão de pedologia. In: CONGRESSO BRASILEIRO DE CIÊNCIA DO SOLO, 24, Goiânia, 1993. n.p. (mimeogr.)

CASES, J.M.; LIETARD, O.; YVON, J.; DELOM, J.F. Étude des 
propritétés cristallochimiques, morphologiques, superficielles de kaolinites désordonnées. Bull. Minéral.,105:439-455, 1981.

CAVALCANTI, A.C. Estudo de latossolos argilosos do Planalto Central do Brasil; caracterização, distinções de acordo com duas superfícies de aplainamento, gênese e classificação. Itaguaí, RJ, UFRRJ, 1977. 186p. (Tese M.S.).

CHAGAS, C.S. Associação de Latossolo Variação Una e Latossolo Vermelho-Escuro; efeito diferencial da orientação dps estratos de rochas pelíticas pobres. Lavras, MG, ESAL, 1994. 124p. (Tese M.S.)

CLINE, M. Origin of the term Latosol. Soil Sci. Soc. Am. Proc., 39: 162, 1975.

CORRÊA, G.F. Modelo de evolução e mineralogia da fração argila de solos do Planalto de Viçosa. MG. Viçosa, UFV, 1984. 87p. (Tese M.S.)

CORRÊA, G.F. \& RESENDE, M. Perfis de cores de solos brasileiros: preposição e um modelo explicativo. Congresso Brasileiro de Ciência do Solo, 23. Porto Alegre, 1991. Programa e Resumos... Porto Alegre, SBCS - UFRGS, 1991. p. 272.

CURI, N. Lithosequence and toposequence of oxisols from Goiás and Minas Gerais States, Brazil. West Lafayette, Purdue University, 1983. 158p. (Tese Ph.D.)

CURI, N. \& FRANZMEIER, D. Toposequence of oxisols from Central Plateau of Brazil. Soil Sci. Soc. Am. J., 48: 341-346, 1984.

DIXON, J.B. Kaolin and serpentine group minerals. In: DIXON, J.B. \& WEED, S.B., eds. Minerals in soil environments. Madison, Soil Science Society of America, 1989. p. 467-526.

EMPRESA BRASILERA DE PESQUISA AGROPECUÁRIA. Centro Nacional de Pesquisa de Solos. Reunião de classificação, correlação e aplicação de levantamento de solos, 4, Rio de Janeiro, 1994. Anais... Rio de Janeiro, EMBRAPA - CNPS, 1995. $157 \mathrm{p}$.

EMPRESA BRASILERA DE PESQUISA AGROPECUÁRIA. Centro Nacional de Pesquisa de Solos. Reunião de classificação, correlação de solos e interpretação de aptidão agrícola, 3, Rio de Janeiro, 1988. Anais... Rio de Janeiro, EMBRAPA - SNLCS/ SBCS, 1988. 425p.

EMPRESA BRASILERA DE PESQUISA AGROPECUÁRIA. Centro Nacional de Pesquisa de Solos. Reunião de classificação, correlação de solos e interpretação de aptidão agrícola, 2, Rio de Janeiro, 1983. Anais... Rio de Janeiro, EMBRAPA - SNLCS/ SBCS, 1983. 138p.

EMPRESA BRASILERA DE PESQUISA AGROPECUÁRIA. Critérios para distinção de classes de solos e de fases de unidade de mapeamento, normas em uso pelo SNLCS. Rio de Janeiro, EMBRAPA-SNLCS, 1988. 67p.

EMPRESA BRASILERA DE PESQUISA AGROPECUÁRIA. Reunião técnica de levantamento de solos, 10. Súmula... Rio de Janeiro, SNLCS, 1979. 83p. (SNLCS - Série Miscelânea, 1).

EMPRESA BRASILERA DE PESQUISA AGROPECUÁRIA. Serviço Nacional de Levantamento e Conservação de Solos. Levantamento exploratório-reconhecimento de solos da margem direita do rio São Franscisco, Estado da Bahia. Recife, Convênios EMBRAPA/SNLCS-SUDENE/DRN, MA/USAID/ ETA. 1977. 296p. (Boletim Técnico, 52).

EMPRESA BRASILERA DE PESQUISA AGROPECUÁRIA. Serviço Nacional de Levantamento e Conservação de Solos. Levantamento exploratório-reconhecimento de solos do Norte de Minas Gerais. (Área de atuação da SUDENE). Recife, 1979. 407p.

EMPRESA BRASILERA DE PESQUISA AGROPECUÁRIA. Serviço Nacional de Levantamento e Conservação de Solos. EMPRESA DE PESQUISA AGROPECUÁRIA DE MINAS GERAIS - Departamento de Recursos Naturais Renováveis. Levantamento de reconhecimento de média intensidade dos solos e avaliação da aptidão agrícola das terras do Triângulo Mineiro. Rio de Janeiro, EMBRAPA-SNLCS/EPAMIG - DRNR, 1982. $526 \mathrm{p}$.

EMPRESA BRASILERA DE PESQUISA AGROPECUÁRIA. Serviço Nacional de Levantamento e Conservação de Solos. Levantamento de reconhecimento de média intensidade dos solos e avaliação da aptidão agrícola das terras do Polo Trombetas, Para. Rio de Janeiro, EMBRAPA-SNLCS, 1984. 440p.
EMPRESA BRASILERA DE PESQUISA AGROPECUÁRIA Centro de Pesquisas Pedológicas. Mapa Esquemático dos Solos das Regiões Norte, Meio-Norte e Centro-Oeste do Brasil. Rio de Janeiro, MA-CONTAP-USAID. 1975. 553p.

ESTADOS UNIDOS. Department of Agriculture. Soil Survey Staff. Soil classification; a comprehensive system. 7th aproximation. Washington, D.C., 1960. 264p.

ESTADOS UNIDOS. Department of Agriculture. Soil Survey Staff. Soil taxonomy; a basin system of classification for making and interpreting soil survey. Washington, D.C., 1975. 330p.

ESTADOS UNIDOS. Soil Survey Staff. Keys to soil taxonomy. United States Department of Agriculture, U.S. Governement Printing Office, 1994. 305p.

FERREIRA, M.M. Influência da mineralogia da fração argila nas propriedades físicas de latossolos brasileiros. Viçosa, MG. UFV, 1988. 79p. (Tese D.S.)

FERREIRA, S.A.D. Relação entre magnetismo e teores de elementos traços em solos de duas regiões de Minas Gerais. Viçosa, MG, UFV, 1991. 94p. (Tese M.S.)

FEUER, R. An exploratory invertigation of the soils and agricultural potencial of the soil of the future Federal District in the Central Plateau of Brazil. Ithaca, Cornell University, 1956. 432p. (Tese Ph.D.)

FITZPATRICK, R.W. \& SCHWERTMANN, U. Al-substituted goethite - an indicator of pedogenic and other weathering environments in South Africa. Geoderma, 27: 335-347, 1982.

FONSECA, O.O.M. Caracterização e classificação de solos latossólicos e podzólicos desencolcidos nos sedimentos de terciário no litoral brasileiro. Itaguaí, RJ, UFRRJ. 1986. 185p. (Tese M.S.)

GOMES, I.A. Oxisols and Inceptsols from gnesis in a subtropical area of Espírito Santo State, Brazil. West Lafayette, Purdue University, 1976. 115p. (Tese M.S.)

GUALBERTO, V.; RESENDE, M.; CURI, N. Química e mineralogia de solos com altos teores de ferro da Amaz^nia e do Planalto Central. R. bras. Ci. Solo, 11:245-252, 1987.

GUIMARÃES, D. A província magmática de Roraima. Rio de Janeiro, MA-DNPM - Divisão de Geologia e Mineralogia. 1947. $107 \mathrm{p}$.

HARRINSON, J.B. The katamorphism of igneous rocks under humid tropical conditions. Harpenden, Imperial Bureau of Soil Science, 1933. 79p.

HERBILLON, A.J. Mineralogy of oxisols and oxidic materials. In: THENG, B.K.G., ed. Soil with variable charge. New Zealand, 1980. p.109-126.

HUGHES, J.C. \& BROWN, G. A cristallinity index for soil kaolins and its relation to parent rock, climate and soil maturity. J. Soil Sci., 30: 557-563, 1979.

JACKSON, M.L. \& SHERMAN, G.D. Chemical weathering of minerals in soils. Adv. Agron. , 5: 219-318, 1953.

JACKSON, M.L. Clay transformation in soil genesis during the quaternary. Soil Sci., 99:15-22, 1964.

JACOMINE, P.K.T. Solos sob caatingas - características e uso agrícola. In: ALVAREZ, V.H.V.; FONTES, L.E.F.; FONTES, M.P.F. eds. Os solos nos grandes domínios morfoclimáticos do Brasil e o desenvolvimento sustentado. Viçosa, SBCS/UFV, 1996. p. 95-112.

JACOMINE, P.T.K. Distribuição geográfica , características e classificação dos solos coesos dos tabuleiros costeiros. In: Reunião técnica sobre solos coesos dos tabuleiros costeiros; Pesquisa e desenvolvimento para os tabuleiros costeiros. Cruz das Almas, 1996. Anais... Aracaju, EMBRAPA - CPATC/ EMBRAPA - CNPMF/EAUFBA/IGUFBA. 1996. p.13-26.

KÄMPF, N. \& SCHWERTMANN, U. Relações entre óxidos de ferro e a cor de solos cauliníticos do Rio Grande do Sul. R. Bras. Ci. Solo, 7: 27-31, 1983.

KÄMPF, N. O ferro no solo. In: REUNIÃO SOBRE FERRO EM SOLOS INUNDADOS, 1, Goiânia, 1988. Anais... Goiânia, EMBRAPA - CNPAF, 1988, P.35-71.

KÄMPF, N.; KLAMT, E.; SCHNEIDER, P. Óxidos de ferro em latossolos do Brasil sul e sudeste. In: Reunião de classificação, correlação de solos e interpretação de aptidão agrícola, 3, Rio de Janeiro, 1988. Anais... Rio de Janeiro, EMBRAPA - SNLCS, SBCS, 1988. p. 153-184. 
KELLER, W.D. The principles of the chemical weathering. Columbia, Lucas Brothers, 1968. 111p.

KELLOG, C.E. Preliminary suggestions for the classification and nomenclature of great soil groups in tropical and equatorial regions. Common. Bur. Soil Sci. Tech. Comm., 46: 76-85, 1949.

KELLOG, C.E. Tropical Soils. In: INTERNATIONAL CONGRESS OF SOIL SCIENCE, 4, Amsterdam, 1950. Proccedings..., Amsterdam, Int. Soil Sci. Soc., 1950. p.266-276.

KER, J. C. Mineralogia, sorção e desorção de fosfato, magnetização e elementos traços de Latossolos do Brasil. Viçosa, MG, UFV, 1995. 181p. (Tese D.S.)

KER, J.C. \& RESENDE, M. Caracterização química e mineralógica de solos brunos subtropicais do Brasil. R. bras. Ci. Solo, 14:215225, 1990.

KER, J.C.; MOTTA, P.E.F.; RESENDE, M. CARVALHO FILHO, A.C. Elementos traços de Latossolos Roxos desenvolvidos de diferentes materiais de origem. In: CONGRESSO BRASILEIRO DE CIÊNCIA DO SOLO, 24, Goiânia, 1993. Resumos... Goiânia, SBCS, 1993. p.319.

KER, J.C.; ALMEIDA, J.A.; FASOLO, P.J.; HOCHMÜLLER, D.P. Levantamento Exploratório de Solos - Folha SH.22 - Porto Alegre e Partes das Folhas SH.21 - Uruguaiana e SI.22 - Lagoa Mirim. In: BRASIL - FIBGE. Rio de Janeiro, IBGE, 1986. p.405540. (Levantamento de Recursos Naturais, Volume 33 Pedologia)

KER, J.C. \& SCHAEFER, C.E. Roteiro da excursão pedológica Viçosa-Sete Lagoas. Congresso Brasileiro de Ciência do Solo, 25. Viçosa, SBCS/DPS - UFV/EMBRAPA - Centro Nacional de Pesquisas de Solos. Viçosa, 1995. 47p.

KING, L.C. A geomorfologia do Brasil Oriental. Rev, bras. Geog., 18147-265, 1956.

LACERDA, L.D.; SOUZA, C.M.M.; PESTANA, M.H.D. Trace metals geochemical associations in sediments of a non contamined estuary. Ciência e Cultura, 41(3): 301-304, 1989.

LEAL, J.R. Adsorção de fosfato em latossolos sob cerrado. Itaguaí, RJ. UFRRJ, 1971. 96p. (Tese M.S.)

LEMOS, R.C. Latolização. In: Processos de formação dos grandes grupos de solos. ETA. Projeto Purdue 55. URMG - Universidade de Purdue. Escola Superior de Agricultura. Viçosa - MG, 1966. 21p. (mimeogr.)

LEPSCH, I. \& BUOL, S.W. Oxisol-landscape relationships in Brazil. In: International soil classification workshop; classificationm characterization and utilization of oxisols, 8. Rio de Janeiro, 1986. Proceedings... Rio de janeiro, EMBRAPA, SMSS, ATD, UPR, 1986. Pt1. p.174-189.

LINDSAY, W.L. Chemical equilibria in soils. New York, John Wiley and Sons, 1979. 449p.

MACEDO, J. \& BRYANT, R.B. Morphology, mimeralogy and genesis of a hydrosequence of oxisols in Brazil. Soil Sci. Soc. Am. J., 51: 690-698, 1987.

MACÍAS VASQUEZ, F. Formation of gibbsite in soils and saprolites of temperate-humid zones. Clay Miner., 16:43-52, 1981.

MATTSON, S. The laws of soil colloidal behavoir; IX. Amphoteric reactions and isoeletric weathering. Soil Sci., 2:209-240, 1932.

MEIRELES, M.C.S. \& RIBEIRO, L.P. Caracterização da sílica em horizontes coesos de solos de tabuleiros. In: Congressi Brasileiro de Ciência do Solo, 25. Viçosa, 1995. Resumos expandidos... Viçosa, SBCS - UFV, 1995. p. 1688-1689.

MESTDAGH, M.M.; VIELVOYE, L.; HERBILLON, A.J. Iron in kaolinite II: the relationship between kaolinite cristalinity and iron content. Clay Miner., 15:1-13, 1980.

MÖLLER, M.R.F. Substituição isomórfica em óxidos de ferro de Latossolos da Amazônia e suas implicações na sorção de fósforo. Piracicaba-SP, ESALQ, 1991. 70p. (Tese D.S.)

MONIZ, A.C. Quantitative mineralogical analysis of Braziliam soils derived from basic rocks and slate. Madison, University of Wisconsin, 1967. 74p. (Tese M.S.)

MOTHCI, E.P. Características, gênese e aptidão agrícola de uma sequência de solos no planalto central brasileiro. Porto Alegre, UFRS - Escola de Agronomia, 1977. 104p. (Tese M.S.)

MOURA FILHO, W. Studies of a Latosol Roxo (Eutrustox) in Brazil. Clay mineralogy, micromorphology effect on ion release, and phosphate reactions. Raleigh, Norte Carolina State University, 1970. 57p. (Ph.D. Thesis)
MOURA FILHO, W. \& BUOL, S.W. Studies of a Latosol Roxo (Eutrustox) in Brazil; micromorphology effect on ion release. Experientiae, 21:161-177, 1976.

NORRISH, K. \& TAYLOR, R.M. The isomorphous replacement of iron by aluminum in soil goethites. J. Soil Sci., 12:294-306, 1961.

NOVAIS. R.F.; NEVES, J.C.L.; BARROS, N.F. Aspectos físicoquímicos envolvidos na fixação de fósforo no solo. In: ENCONTRO NACIONAL DE ROCHA FOSFÁTICA, 5, São Paulo, 1991. Anais..., São Paulo, 1991. p. 133-177.

OADES, J.M. The nature and distribution of iron compounds in soils. Soils Fert., 26:69-80, 1963.

OLIVEIRA, J.B.; JACOMINE, P.K.T.; CAMARGO, M.N. Classes gerais de solos do Brasil - guia auxiliar para seu reconhecimento. Jaboticabal, FUNEP, 1992. 201p.

OLIVEIRA, J.B.; RESENDE, M.; CURI, N. Caracterização e classificação de latossolos variação una e de solos afins da região de Guaíra - SP. R. bras. Ci. Solo, 15:207-218, 1991.

OLIVEIRA, J.B. \& MENK, J.R.F. Latossolos Roxos do Estado de São Paulo. Campinas, Instituto Agronômico, 1984. 135p. (Boletim Técnico, 82).

OLIVEIRA, V.; COSTA, A.M.R.; AZEVEDO, W.P.; CAMARGO, M.N.; LARACH, J.O.I. Levantamento Exploratório de Solos Folhas SF.23/24 - Rio de Janeiro/Vitória. In: BRASIL - MME. Secretaria Geral, Rio de Janeiro, 1983. Projeto RADAMBRASIL. p. 385-552. (Levantamento de Recursos Naturais, Volume 32 - Pedologia)

OLLIER, C.D. A two-cycle theory of soil genesis. J. Soil Sci., 10:137148,1959

PALMIERI, F. A study of a climosequence of soils derived from volcanic rock parent material in Santa Catarina and Rio Grande do Sul States, Brazil. West Lafayette, Purdue University, 1986. 259p. (Tese Ph.D.)

PANOSO, L.A. Latossolo Vermelho-Amarelo de tabuleiro do Espírito Santo. Recife, PE, UFRP, 1976. 115p. (Tese de Livre Docência)

PESSOAS, S.C.P. Estudo de uma sequência de perfis de podzólicos e latossolos desenvolvidos de granulitos na zona úmida costeira, Sul do Estado da Bahia. Salvador, UFB, 1979. 146p. (Tese M.S.)

PLAÇON, A \& TCHOUBAR, C. Determination of structural defects in phyllosilicates bu x-ray powderdiffraction: II: nature and proportion of defects in natural kaolinites. Clays Clay Min., 25: 436-450. 1977.

PÖTTER, R.O. \& KÄMPF, N. Argilo-minerais e óxidos de ferro em cambissolos e latossolos sob regime climático térmico údico no Rio Grande do Sul. R. bras. Ci. Solo, 5:153-159, 1981.

RANSOM, M.D.; SMECK, N.E.; BIGHAM, J.M. Stratigraphy and genesis of polygenetic soils on the Illinoian till plain of Southwestern Ohio. Soil Sci. Soc. Am. J., 51: 135-141, 1987.

RAUEN, M.J. Mineralogical identification of a topossequence of soils from basaltic rocks in the state of Parana, Brazil. West Lafayette, Purdue University, 1980. 161p. (Tese M.S.)

RESENDE, M. Mineralogy, chemistry, morphology and geomorphology of some soils of the Central Plateau of Brazil. West Lafayette, Purdue University, 1976. 237p. (Tese Ph.D.)

RESENDE, M.; SANTANA, D.P.; REZENDE, S.B. Susceptibilidade magnética em Latossolos do sudeste e sul do Brasil. In: Reunião de classificação, correlação de solos e interpretação de aptidão agrícola, 3, Rio de Janeiro, 1988. Anais... Rio de Janeiro, EMBRAPA - SNLCS/SBCS, 1988. p. 233-258.

RESENDE, M.; SANTANA, D.P.; FRANZMEIER, D.P.; COEY, J.M.D. Magnetic properties of brazilian oxisols. In: International soil classification workshop; classification, characterization and utilization of oxisols, 8, Rio de Janeiro, 1986. Proceedings... Rio de Janeiro, EMBRAPA, SMSS, ATD, UPR, 1986. Pt. 1, p. 78108.

RESENDE, M. \& KER, J.C. Pedologia e interações geomédicas. In: Seminário sobre interações geomédicas, 2. Areia, 1996. 31p.

REZENDE, S.B. Geomorphology, mineralogy and genesis of four soils on gneiss in southeastern Brazil. West Lafayette, Purdue University, 1980. 143p. (Tese Ph.D.)

RIBEIRO, A.C.; RESENDE, M.; FERNANDES, B. Latossolos com horizonte subsuperficial escurecido na região de Viçosa. Revista Ceres, 19:280-298, 1972.

RODRIGUES, T.E. Solos da Amazônia. In: ALVAREZ, V.H.V.; 
FONTES, L.E.F.; FONTES, M.P.F. eds. Os solos nos grandes domínios morfoclimáticos do Brasil e o desenvolvimento sustentado. Viçosa, SBCS/UFV, 1996. p. 16-60.

RODRIGUES, T.E. Caracterização e gênese de solos brunos do maciço alcalino de Poços de Caldas - MG. Piracicaba, ESALQ, 1984. 255p. (Tese D.S.)

SANTANA, D.P. Soil formation in a toposequence of oxisols from Patos de Minas region, Minas Gerais State, Brazil. West Lafayette, Purdue University, 1984. 129p. (Tese Ph.D.)

SANTOS, A.R. Caracterização mineralógica e avaliação da reserva mineral de alguns nutrientes, em solos sob eucalipto, da região do Vale do Rio Doce. Viçosa, UFV, 1993. 97p. (Tese M.S.)

SCHAEFFER, C.E.G.R. Ambientes no nordeste de Roraima: solos palinologia e implicações paleoclimáticas. Viçosa, UFV, 1991. 114p. (Tese M.S.)

SCHULZE, D.G. The identification of iron oxides by differential $\mathrm{x}$ ray diffraction and the influence of aluminum substitution on the structure of goethite. Weihenstephan, Lehrtuhl für Bodenkunde der Technischen Universität Nünchen, 1982. 167p. (Tese Ph.D).

SCHWERTMANN, $\mathrm{U}$. The effect of environments on iron oxide minerals. Adv. Soil Sci., 1:172-200, 1985.

SCHWERTMANN, U. Transformation of hematite to goethite in soils. Nature, 232:64-65, 1971

SCHWERTMANN, U. \& KÄMPF, N. Properties of goethite and hematite in kaolinitic soils of Southern and Central Brazil. Soil Sci., 139:344-350, 1985.

SCHWERTMANN, U. \& LENTZE, W. Bodenfarbe and eisenoxidform. Z. Pflanzenernahr. Bodenkd., 115: 209-214, 1966.

SCHWERTMANN, U. \& TAYLOR, R.M. Iron Oxides. In: DIXON, J.B. \& WEED, S.B., eds. Minerals in soil environments. Madison, Soil Science Society of America, 1977. p. 145-180.
SCHWERTMANN, U. Occurrence and formation of iron oxides in various pedoenvironments. In: STUCKI, J.W.; GOODMAN, B.A. \& SCHWERTMANN, U. eds. Iron in soils and clay minerals. D. reidel Publishing Company, 1988. 893p.

SÉGALEN, P. Contribution à la connaissance de la couleur des sols sesquioxides de la zone intertropicale; sols jaunes et sols rouges. Cah. ORSTOM, Sér. Pédol., 2:113-236, 1969.

SÉGALEN, P. Les sols ferrallitiques et leur répartition géographique. Tome 1. Introduction générale. Les sols ferrallitiques: leu identification et environnement immédiat. Paris, editions de l'ORSTOM. Collection Études et Théses. 1994. 197p.

SILVA, F.B.R. Cambissolos da porção central da província estrutural da Mantiqueira e suas relações com os Latossolos; alteração e pedogênese. São Paulo, USP, 1985. 261p. (Tese D.Sc.)

SOMBROEK, W.G. Amazon soils. Wageningen, Center for Agricultural Publications and Documentation, 1966. 292p. (Agricultural Research Reports, 672).

SOUZA, G.A. Estudo comparativo de propriedades de latossolos do Brasil. Porto Alegre, RS, UFRGS, Escola de Agronomia, 1979. 105p. (Tese M.S.)

THORP, J. \& SMITH, G.D. Higher categories of soil classification: order, suborder and great soil groups. Soil Sci., 67: 177-226, 1949.

UNIVERSIDADE FEDERAL DE SANTA MARIA e SUPERINTENDÊNCIA DO DESENVOLVIMENTO DA REGIÃO SUL. Levantamento de reconhecimento dos solos no Estado de Santa Catarina. Santa Maria. UFSM, 1973, 2v.

UNIVERSIDADE FEDERAL DE VIÇOSA. Caracterização de solos e avaliação dos principais sistemas de manejo dos tabuleiros costeiros do Baixo Rio Doce e da Região Norte do Estado do Espírito Santo e sua interpretação para uso agrícola. Viçosa, UFV, 1984. 153p. 